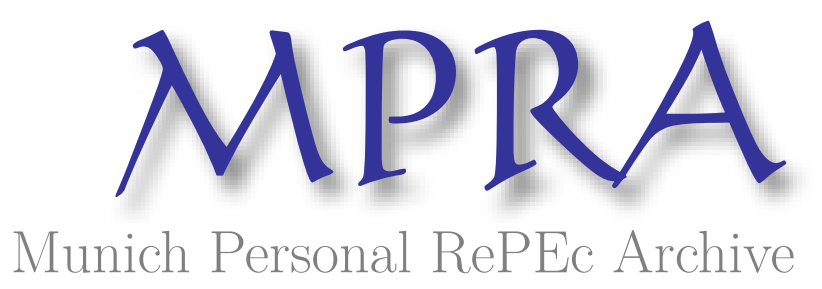

Can Second-Generation Endogenous Growth Models Explain The Productivity Trends and Knowledge Production In the Asian Miracle Economies?

\author{
Ang, James and Madsen, Jakob \\ Monash University
}

2009

Online at https://mpra.ub.uni-muenchen.de/17543/

MPRA Paper No. 17543, posted 27 Sep 2009 16:57 UTC 


\title{
Can Second-Generation Endogenous Growth Models Explain The Productivity Trends And KnOWledge Production In the Asian Miracle Economies?
}

\author{
James B. Ang * and Jakob B. Madsen \\ Department of Economics \\ Monash University
}

\begin{abstract}
Using data for six Asian miracle economies over the period from 1953 to 2006, this paper examines the extent to which growth has been driven by $R \& D$ and tests which second-generation endogenous growth model is most consistent with the data. The results give strong support to Schumpeterian growth theory but only limited support to semi-endogenous growth theory. Furthermore, it is shown that R\&D has played a key role for growth in the Asian miracle economies.
\end{abstract}

Keywords: Schumpeterian growth; semi-endogenous growth; Asian growth miracle

JEL classification: $\mathrm{O} 30$; $\mathrm{O} 40$

\footnotetext{
* Corresponding author: Department of Economics, Monash University, 900 Dandenong Road, Caulfield East, Vic 3145 Australia. E-mail: James.Ang@buseco.monash.edu.au.

Acknowledgements: helpful comments and suggestions received from seminar participants of the Melbourne Institute of Applied Economic and Social Research at the University of Melbourne. The authors acknowledge financial support from the Australian Research Council.
} 


\section{Introduction}

R\&D-based endogenous growth theories have been increasingly used to explain growth in the OECD industrialised countries (see, e.g., Coe and Helpman, 1995; Zachariadis, 2003, 2004; Kneller and Stevens, 2006; Ha and Howitt, 2007; Madsen, 2007, 2008a). These studies show that productivity growth in OECD countries has been driven by R\&D, technology spillovers through the channel of imports and their technology absorptive capacity. Given the central role the Asian miracle economies have held in the literature on growth and development, it is amazing how little attention has been given to R\&D-driven growth in these countries. Easterly (1994), Rodrik $(1995,1996,1997)$ and Radelet et al. (2001) find that the literature on the Asian miracles attributes the success of these countries to outward orientation, market friendly policies, education and a stable macroeconomic and political environment, among other factors. Very little, if any, of the literature has considered the possibility of R\&D-driven growth among these economies, which may be due to the difficulties in finding R\&D data. Since the fraction of $R \& D$ in total income in the miracle economies is little more than half the ratio of the countries at the technology frontier, R\&D driven growth may potentially be important in the miracle economies. $^{1}$

An equally important issue is the functional relationship between growth and R\&D in the Asian miracle economies. Following Jones' (1995b) critique of the predictions of the first-generation endogenous growth models of Romer (1990) and Aghion and Howitt (1992), a positive relationship between the levels of $R \& D$ and productivity growth is generally no longer accepted as an empirical regularity in the growth literature. Instead, the second-generation models such as Schumpeterian and semi-endogenous growth theory have gradually become the dominant paradigm. However, these second-generation growth models have not been tested for general validity. Ha and Howitt (2007) and Madsen (2008b) find that the Schumpeterian growth model is the second-generation endogenous growth model that best explains growth in the US and the mature OECD countries. However, these findings need not hold for economies such as the Asian miracles that have undergone marked growth spurts.

This paper examines which of the two second-generation endogenous growth models best explains the relationship between $R \& D$ and growth and the role played by $R \& D$ in explaining growth in the Asian miracle economies. We consider the following six miracle economies for which R\&D data

\footnotetext{
${ }^{1}$ R\&D expenditure as a percentage of GDP is on average (unweighted) slightly above 1.3 percent for the miracle economies (China, India, Japan, Korea, Taiwan, and Singapore) during the period 1953-2006 while the percentage is 2.4 for the US, Germany, Italy, France and the UK, on average, over the same period.
} 
are available over most of the period from 1953 to 2006: China, India, Japan, Korea, Singapore and Taiwan. Three sets of tests are undertaken. The first set of tests involves tests of unit roots and cointegration. The second set examines whether TFP growth can be explained by R\&D in a way that is consistent with the theories. The last set estimates ideas production functions in which knowledge production is explained by $R \& D$ or $R \& D$ intensity and the stock of knowledge. Finally, we check the robustness of the results by controlling for the effects of distance to the technology frontier (Dowrick and Gemmell, 1991; Aghion et al., 2005; Acemoglu et al., 2006; Aghion and Howitt, 2009), trade openness (Vamvakidis, 2002), technology spillovers (Coe and Helpman, 1995) and transitional dynamics (Peretto, 1999; Howitt, 2000), and consider different estimation periods.

The paper proceeds as follows: the next section discusses the theoretical and empirical implications of endogenous growth models. Section 3 discusses the construction of variables and provides some preliminary graphical analysis. The empirical analysis is conducted and presented in Section 4. The last section concludes the paper.

\section{Productivity Growth and Ideas Production}

Endogenous growth models emphasize innovation as the engine of growth. In the firstgeneration endogenous growth models of Romer (1990), Segerstrom et al. (1990), Grossman and Helpman (1991) and Aghion and Howitt (1992), TFP growth is positively related to the levels of R\&D. This leads to an assumption of scale effects in ideas production, i.e., new ideas are proportional to the stock of knowledge. However, these models are not consistent with the evidence. In particular, Jones (1995a, b) shows that the significantly increasing number of scientists and engineers engaged in R\&D in the US since the 1950s has not been followed by a concomitant increase in the growth rate of TFP, thus refuting the first-generation R\&D-based endogenous growth models.

Consequently, endogenous growth theory has evolved into the two following second-generation theories: semi-endogenous growth models and Schumpeterian growth theory. The semi-endogenous models of Jones (1995a), Kortum (1997) and Segerstrom (1998) abandon the scale effects in ideas production by assuming diminishing returns to the stock of $R \& D$ knowledge. Thus, $R \& D$ has to increase continuously to sustain a positive TFP growth. The Schumpeterian growth models of Aghion and Howitt (1998), Dinopoulos and Thompson (1998), Peretto (1998), Young (1998), Howitt (1999) and Peretto and Smulders (2002) maintain the assumption of constant returns to the stock of R\&D knowledge. However, they assume that the effectiveness of $R \& D$ is diluted due to the proliferation of products as the economy expands. Thus, growth can still be sustained at a constant level if R\&D is kept 
to a fixed proportion of the number of product lines, which is in turn proportional to the size of the population along the balanced growth path. As such, to ensure sustained TFP growth, R\&D has to increase over time to counteract the increasing range and complexity of products that lowers the productivity effects of R\&D activity.

The following knowledge production function can be used to discriminate between endogenous growth theories (see, e.g., Ha and Howitt, 2007; Madsen, 2008b):

$$
\begin{aligned}
& \frac{\dot{A}}{A}=\lambda\left(\frac{X}{Q}\right)^{\sigma} A^{\phi-1}, \\
& Q \propto L^{\beta} \text { in steady state }
\end{aligned}
$$

where $\dot{A}$ is the number of new ideas generated, $A$ is the stock of knowledge, $\lambda$ is a research productivity parameter, $X$ is innovative activity, $Q$ is product variety, $\sigma$ is a duplication parameter ( 0 if all innovations are duplications and 1 if there are no duplicating innovations), $\phi$ is returns to scale in knowledge, $L$ is employment or population, and $\beta$ is the parameter of product proliferation. Innovative activity, $X$, is measured as $\mathrm{R} \& \mathrm{D}$ input for semi-endogenous growth theory or the productivity-adjusted R\&D input for the Schumpeterian growth theory, where the productivity adjustment allows for the increasing complexity of innovations. Thus, the growth enhancing effect of $R \& D$ input is counterbalanced by the negative effect of product variety (Ha and Howitt, 2007).

Endogenous growth models can be distinguished by the parameters $\phi$ and $\beta$. Semiendogenous theory assumes $\phi<1$ under the assumption of diminishing returns to knowledge and the absence of product proliferation effects $(\beta=0)$. Schumpeterian theory maintains constant returns to knowledge $(\phi=1)$ and the presence of a product variety effect $(\beta=1)$. First-generation endogenous growth models assume constant returns to knowledge $(\phi=1)$ and the absence of product proliferation effects $(\beta=0)$.

\subsection{Empirical Implications of Endogenous Growth Models}

Eq. (1) has three empirical implications that are used in this paper to discriminate between endogenous growth models. The first two tests relate to the implications of the models along the balanced growth path. The third test estimates ideas production functions directly and, as such, holds regardless of whether the economy is on a transitional path or moving along its balanced growth path. These tests are as follows. 
The first test considers the long-run relationship between the variables. Taking logs of Eq. (1) yields:

$$
\ln \left(\frac{\dot{A}}{A}\right)=\ln \lambda+\sigma\left[\ln X-\ln Q+\left(\frac{\phi-1}{\sigma}\right) \ln A\right]=\ln \lambda+\sigma Z,
$$

where $Z=\ln X-\ln Q+[(\phi-1) / \sigma] \ln A$. This equation can be approximated to the following empirical counterpart (Ha and Howitt, 2007):

$$
\Delta \ln A_{i t}=\ln \lambda+\sigma Z_{i t}+\varepsilon_{i t},
$$

where $\varepsilon_{i t}$ is a stochastic error term. If $\Delta \ln A_{i t}$ is stationary, $Z_{i t}$ must be stationary and the variables contained in $Z$ must form a cointegrated relationship for growth theories to be consistent with empirical evidence. When $A$ is measured by TFP, $\Delta \ln A_{i t}$ is found to be stationary (see Greasley (1992) for the UK, Abdih and Joutz (2006) and Ha and Howitt (2007) for the US and Madsen et al. (2009) for India).

Imposing the parameter restrictions as suggested by the second-generation growth theories and measuring $A$ by TFP (denoted as $A^{T}$ ) imply that the terms $v_{i t}$ and $\varsigma_{i t}$ in the following equations are stationary:

Semi-endogenous growth theory: $\quad v_{i t}=\ln X_{i t}+[(\phi-1) / \sigma] \ln A_{i t}^{T}$,

Schumpeterian growth theory: $\quad \varsigma_{i t}=\ln X_{i t}-\ln Q_{i t}$.

Due to the assumption of diminishing returns to the knowledge stock, semi-endogenous growth theory predicts the coefficient of $\ln A_{i t}^{T}$ in Eq. (4) to be negative. Therefore, if semi-endogenous growth theory holds, one would expect (i) both $\ln X_{i t}$ and $\ln A_{i t}^{T}$ to be non-stationary and integrated of the same order; and (ii) both variables to be cointegrated with the cointegration vector of $\left(1 \frac{\phi-1}{\sigma}\right)$, where the second element in the vector is expected to be negative. The Schumpeterian growth models predict that: (i) $\varsigma_{i t}=\ln (X / Q)$ is stationary and (ii) $\ln X_{i t}$ and $\ln Q_{i t}$ are cointegrated with the cointegration vector of $\left(\begin{array}{ll}1 & -1\end{array}\right)$.

While the above cointegration analysis yields insight into the validity of each second-generation endogenous growth model, the approach may be appropriate only when the economies are close to or 
on their balanced growth paths. For economies that are traveling along their transitional paths, the longrun relationship implied by the theory may not be observed (see Ha and Howitt, 2007). Since the economies covered in our sample may not always have been in their steady states within the sample period considered, the cointegration analysis is supplemented by two additional tests: a productivity growth model and a direct estimation of ideas production functions.

The following TFP growth equation is regressed following the approach of Madsen (2008b): ${ }^{2}$

$$
\Delta \ln A_{i t}^{T}=\beta_{0}+\beta_{1} \Delta \ln X_{i t}+\beta_{2} \ln (X / Q)_{i t}+\varepsilon_{1, i t} .
$$

Semi-endogenous growth models predict that $\beta_{1}>0$ and $\beta_{2}=0$ whereas Schumpeterian growth theory predicts that $\beta_{2}>0$. Since R\&D has transitional growth effects in Schumpeterian growth models, a positive $\beta_{1}$ is also consistent with Schumpeterian growth theory. Eq. (6) is estimated with and without control variables.

The productivity growth equation is a useful complement to the cointegration analysis for the following two reasons. First, estimates of TFP growth models overcome some of the restrictions imposed on the variables in the cointegration analysis. TFP may not be cointegrated with innovative activity as predicted by semi-endogenous growth theory because of the omission of other trended variables that may be influential for the TFP path such as human capital. For Schumpeterian theory, $\ln X$ and $\ln Q$ may not be cointegrated because product variety may not be precisely measured. Second, that $\ln X$ and $\ln Q$ are cointegrated does not necessarily imply that research intensity is a driving force behind productivity growth, as predicted by Schumpeterian theory. The productivity growth equation overcomes this deficiency.

In the third test, ideas production functions are estimated directly. Taking logs of Eq. (1) and imposing the restrictions implied by the theories yield the following specifications:

$$
\begin{array}{ll}
\ln \dot{A}_{i t}^{I}=\alpha_{0}+\alpha_{1} \ln X_{i t}+\alpha_{2} \ln A_{i t}^{I}+\varepsilon_{2, i t}, & \text { Semi-endogenous } \\
\ln \dot{A}_{i t}^{I}=\gamma_{0}+\gamma_{1} \ln (X / Q)_{i t}+\gamma_{2} \ln A_{i t}^{I}+\varepsilon_{3, i t} . & \text { Schumpeterian }
\end{array}
$$

where $\dot{A}^{I}$ refers to the production of new ideas and $A_{i t}^{I}$ is the stock of existing ideas. Here, the production of new ideas is measured by patent applications and the stock of existing ideas is measured

\footnotetext{
${ }^{2}$ Imposing the restrictions hypothesized by Schumpeterian theory and taking logs of Eq. (1) yields the approximation: $\Delta \ln A^{T}=\ln \lambda+\sigma \ln (X / Q)$. Under the maintained hypothesis of semi-endogenous growth theory, total differentiating Eq. (4) yields: $\Delta \ln A^{T}=[\sigma /(1-\phi)] \Delta \ln X-[\sigma /(1-\phi)] \Delta v$. Thus, Eq. (6) is obtained by nesting these two equations.
} 
by the stock of patents as detailed below. Semi-endogenous growth theory assumes diminishing returns to the stock of knowledge $\left(0<\alpha_{2}<1\right)$ and the generation of new ideas is proportional to $\mathrm{R} \& \mathrm{D}$ $\left(\alpha_{1}>0\right)$. Schumpeterian growth models retain the assumption of constant returns to the stock of knowledge $\left(\gamma_{2}=1\right)$ and a positive growth-enhancing effect of research intensity $\left(0<\gamma_{1}<1\right)$.

A direct test on ideas production functions has several advantages compared to the other tests. First, and most importantly, the estimates of ideas production functions are not influenced by transitional dynamics, rendering this approach suitable for both developing and developed countries regardless of how far away they are from their steady states. Ideas production functions hold at any point in time whereas the growth equation and, particularly, the cointegration equations only hold when the economies are close to or are along their balanced growth paths. It is well know that it takes several years for an economy to get even close to its balanced growth path and thus the estimates may be biased unless transitional dynamics have been explicitly dealt with.

Second, an approximation of $\ln (\dot{A} / A)$ by $\Delta \ln A$ is not required since the number of patent applications is always positive whereas TFP is not always growing at positive rates due to cyclical influences and measurement errors. Third, since ideas production functions are not influenced by cyclicality and transitional dynamics, it can be estimated using annual data, thus providing a substantial increase in the number of observations in estimation. Fourth, the presence of scale effects can only be tested under the framework of an ideas production function.

Finally, new ideas are measured directly by patents instead of indirectly by TFP. There are two principal problems associated with the use of TFP: 1) it combines knowledge as well as efficiency. Two economies with the same stock of knowledge may have quite different levels of TFP due to the fact that one utilizes its resources more effectively than the other. To the extent that efficiency is changing at different rates across countries, TFP provides an imprecise measure of knowledge stock; 2) it is also well-known that the use of TFP is subject to some measurement problems. Griliches (1979) has demonstrated that productivity accounts are biased and that productivity cannot be measured in many sectors of the economy. Aghion and Howitt (1998, pp. 442-447) have also shown that TFP growth rates are underestimated due to the difficulties associated with measuring quality improvement in national accounts. ${ }^{3}$

\footnotetext{
${ }^{3}$ The use of patents as a measure of innovative output, however, is also subject to some criticisms since the quality of patents may vary over time, not all inventions are patented, the propensity to patent may change over time, and the high costs of patenting give inventors some incentives to keep their inventions secret (see Boehm and Silberston, 1967).
} 


\section{Data and Graphical Analysis}

Annual data over the period 1953-2006 are used in the empirical analysis. These data are obtained from various domestic and international sources. A full description of the variables and their sources are provided in the data appendix. TFP is computed as $A^{T}=Y /\left(K^{\alpha} L^{1-\alpha}\right)$, where $Y$ is real GDP, $L$ is employment and $K$ is non-residential capital stock based on the perpetual inventory model. Capital's income share $(\alpha)$ is set to 0.3 , following the established practice in the literature (see, e.g., Aghion and Howitt, 2007). A depreciation rate of 3 percent is assumed for non-residential buildings and structures and 17 percent for machinery and equipment (see Madsen, 2007). Investment data from the earliest available years have been used to generate the initial stock for the year 1953. The initial capital stock is obtained by dividing initial investment by the sum of the depreciation rates and the average geometric growth rates of real investment over the entire data period. Ideas $\left(\dot{A}^{I}\right)$ are measured by the number of patents applied for by domestic residents. The stock of knowledge $\left(A^{I}\right)$ is computed using the perpetual inventory method with a depreciation rate of $15 \%$, following Hall et al. (2005).

Innovative activity $(X)$ is measured by real $\mathrm{R} \& \mathrm{D}$ expenditures $(R)$ and number of $\mathrm{R} \& \mathrm{D}$ workers $(N)$. Nominal R\&D expenditure is deflated by an unweighted average of the economy-wide valueadded price deflator and hourly earnings following Coe and Helpman (1995). In line with Ha and Howitt (2007), the following measures of research intensity are used: $R / Y, R / A^{T} L, N / L$ and $N / h L$, where $h$ is human capital per worker and is measured as educational attainment. The data for educational attainment are mainly obtained from Barro and Lee (2001). The second measure of research intensity, $R / A^{T} L$, is adjusted for TFP given that innovation may become more complex as technology deepens (Ha and Howitt, 2007).

The natural logarithm of the TFP series is displayed in Figure $1(1953=100)$. China, Japan and Taiwan have experienced the strongest TFP growth rates and India the lowest over the period from 1953 to 2006. The lead of China, Japan and Taiwan over the other countries in 2006 is an outcome of the growth spurts in the period 1953-70 for Japan and Taiwan and the period 1980-2006 for China.

Figure 1: Logs of TFP (1953-2006) 


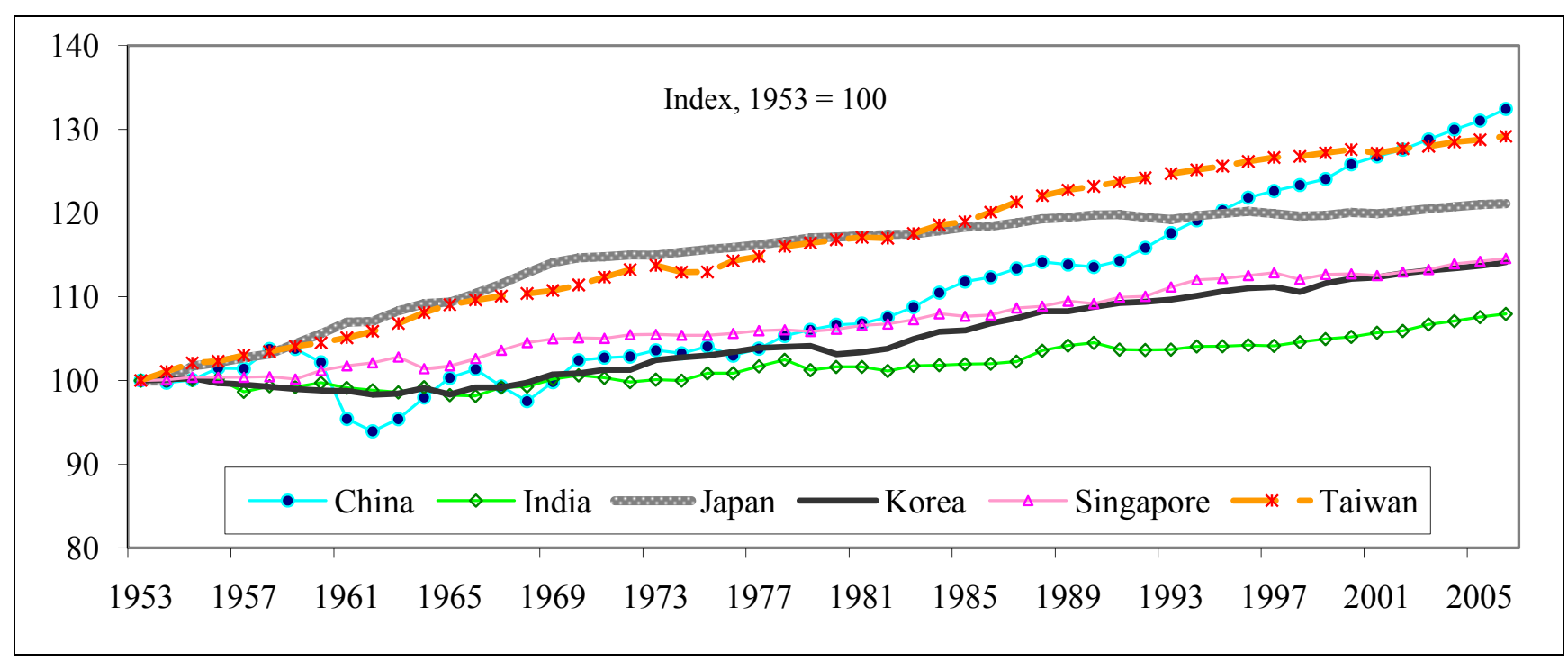

Figure 2: Average TFP Growth and Growth Rates of R\&D Activities (1953-2006)

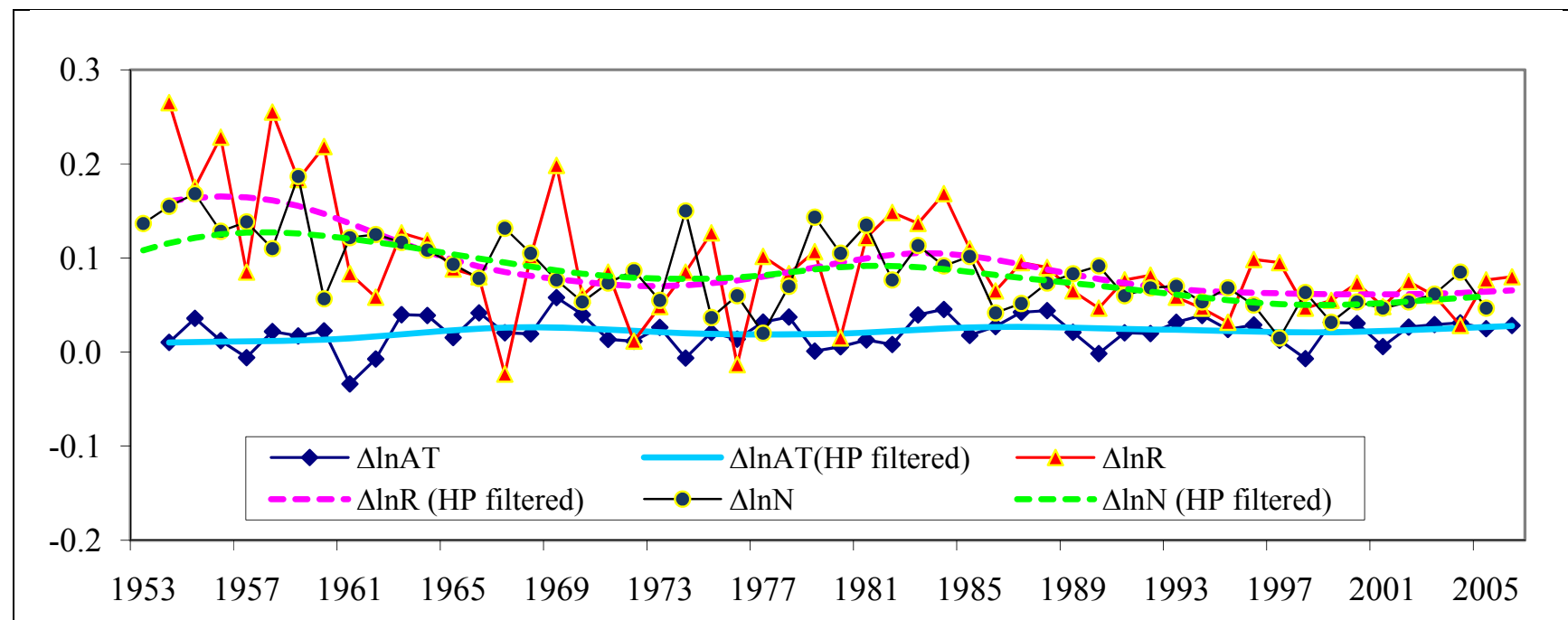

Notes: data are unweighted averages of the six countries considered in the panel. $A T=$ total factor productivity measured by TFP, $R=$ real R\&D expenditure, and $N=\mathrm{R} \& \mathrm{D}$ labor. A smoothing parameter of 100 is used to generate the Hodrick-Prescott (HP) series. The growth rates are measured in percentages.

Figures 2 to 5 provide graphical evidence on the ability of the second-generation endogenous growth models in explaining TFP growth in the Asian miracle economies. The data series in Figures 2 and 4 show unweighted averages of all six Asian countries whereas Figures 3 and 5 show the data for individual countries. First, consider semi-endogenous growth theory. Figure 2 indicates declining trends in growth rates of both real $R \& D$ expenditures and the number of $R \& D$ workers over the period 1953-2006. The trend in the TFP growth rates, on the other hand, has been relatively constant with a very weak increasing tendency. Figure 3 shows that all countries have experienced either declining or 
constant $R \& D$ growth rates. These paths provide little support for semi-endogenous growth since they suggest the absence of a common trend between R\&D inputs and TFP.

Figure 3: Growth Rates of R\&D expenditure for individual countries (1953-2006)

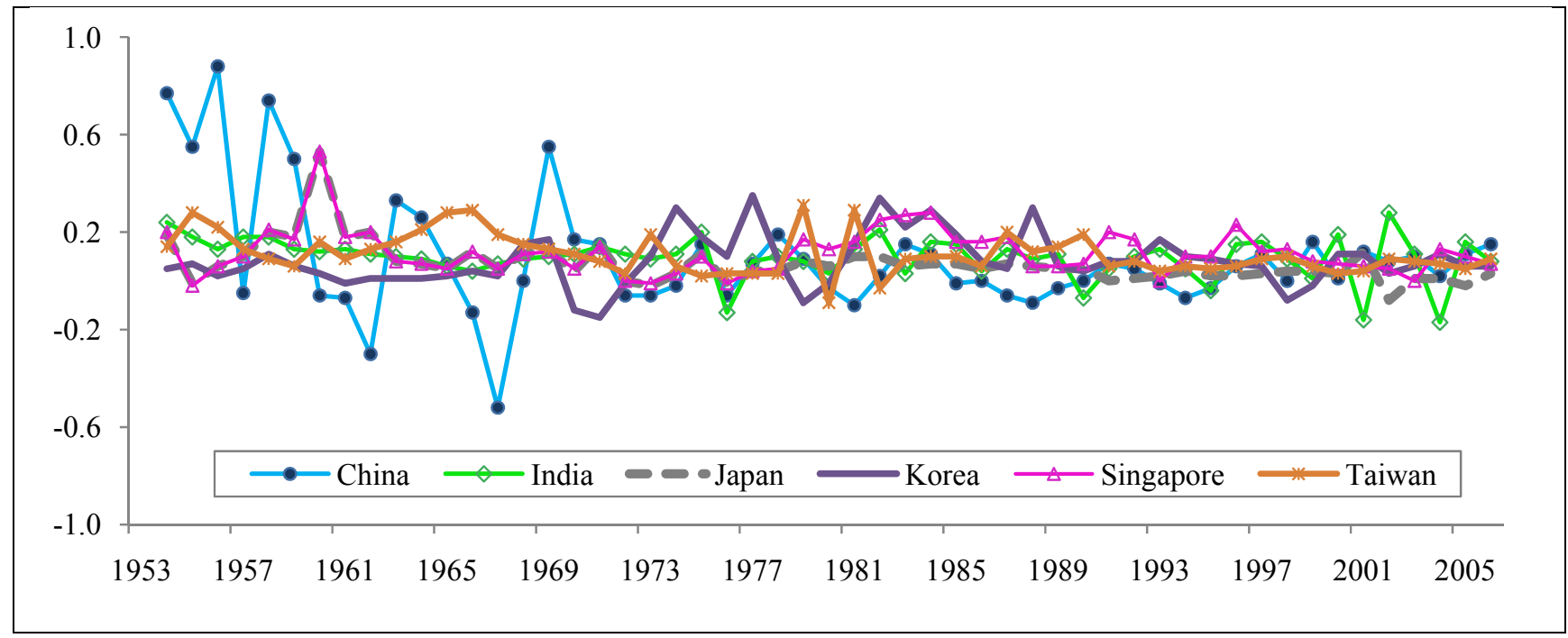

Figure 4: Average TFP Growth Rates and R\&D Intensity (1953-2006)

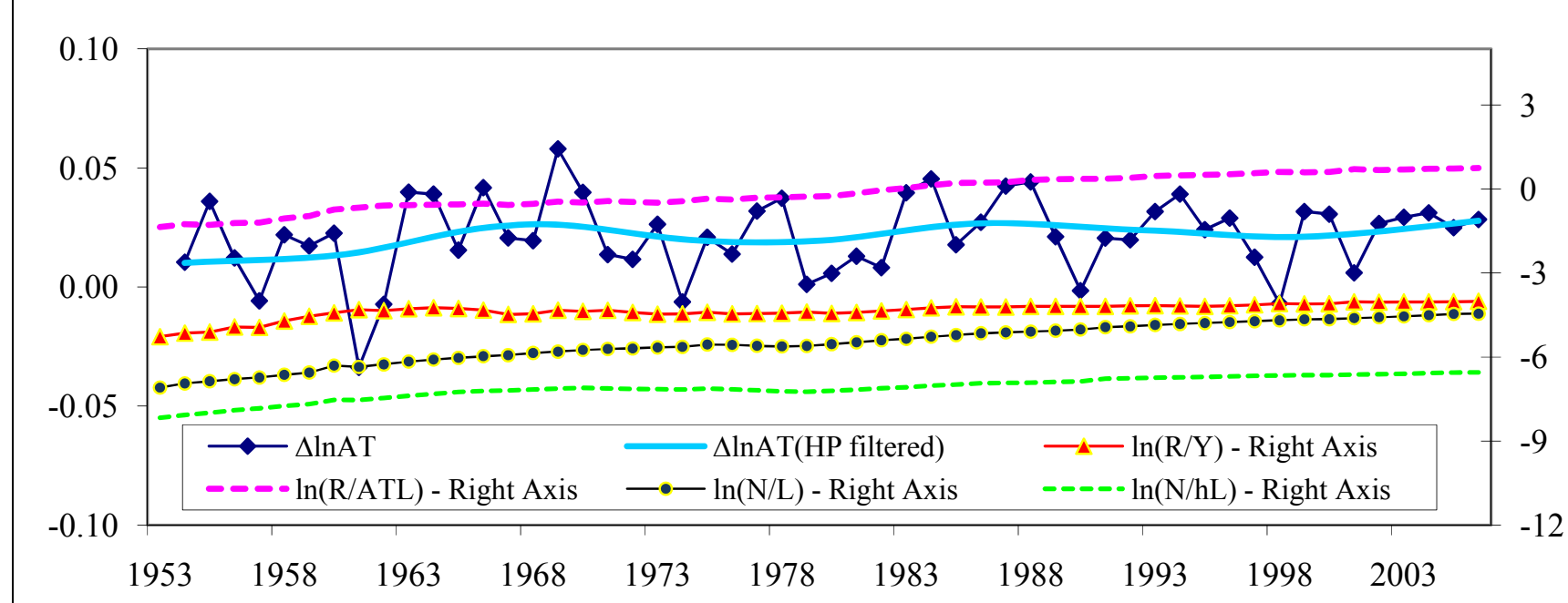

Notes: data in the diagrams represent averages of the six countries considered in the panel. $A T=\mathrm{TFP}, R=$ real R\&D expenditure, $Y=$ real GDP, $N=$ R\&D labor, $L=$ labor force, $A T L=$ TFP multiplied by the labor force, and $h=$ educational attainment. A smoothing parameter of 100 is used to generate the Hodrick-Prescott (HP) series.

The relevant time series plots for the analysis of the Schumpeterian growth models are presented in Figures 4 and 5. Figure 4 depicts that the unweighted averages of various measures of research intensity show either constant or slightly increasing trends. Since TFP has been growing at a 
constant to a very slightly increasing rate, this informal evidence gives some support for Schumpeterian growth theory. Figure 5 shows that except for India, where the share of R\&D expenditure in GDP has increased steadily over time, $R \& D$ intensity in these miracle economies is not clearly associated with an upward or downward trend. ${ }^{4}$ Overall, the graphical analysis provides more support for Schumpeterian growth theory but less evidence for semi-endogenous growth theory.

Figure 5: Logs of R\&D expenditure / GDP of individual countries (1953-2006)

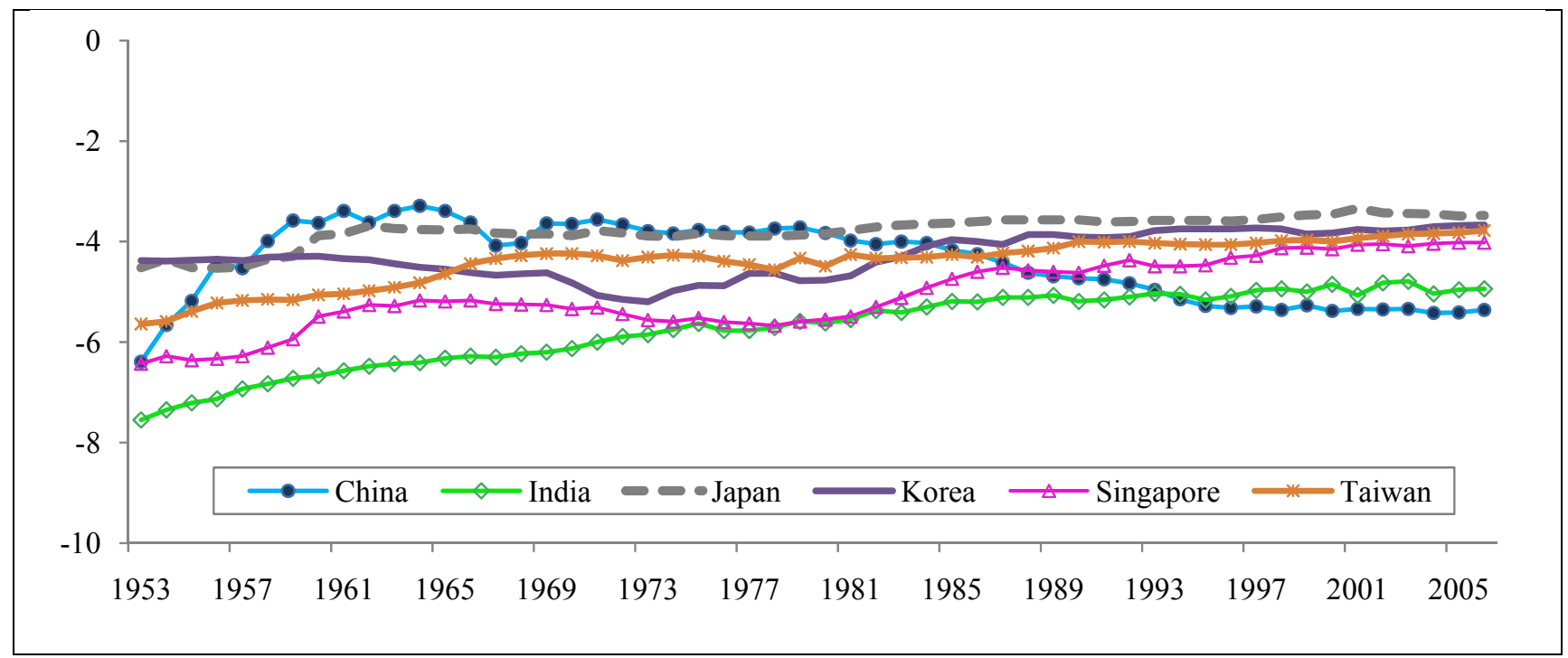

\section{Empirical Results}

\subsection{Integration Analysis}

This section performs the unit root tests for the relevant variables to assess the validity of each endogenous growth theory based on the framework set out in Section 3. The integration properties of the underlying variables are examined using several panel unit root tests, including that of Levin et al. (2002), Breitung (2000), Im et al. (2003), the Fisher-type tests using ADF and PP tests of Maddala and $\mathrm{Wu}$ (1999) and Choi (2001), respectively.

Semi-endogenous growth requires TFP and R\&D levels to be integrated at the same order. The results in Table 1 show that while $\ln A^{T}$ is found to contain a unit root in all cases but one, neither $\ln R$ nor $\ln N$ appears to be non-stationary. Based on the 10 percent decision rule, $\ln R$ is $I(0)$ in four out of five cases whereas $\ln N$ is stationary in three out of five cases. Thus, based on these tests, there is very

\footnotetext{
${ }^{4}$ Formal stationarity tests confirm the visual inspection. Based on the $\mathrm{Ng}$ and Perron (2001) approach and the endogenous two-break unit root procedure of Lee and Strazicich (2003), the null of unit root is consistently rejected at the 5\% level of significance for $\ln R / Y$ for individual countries. Similar results are obtained for the variables $\ln (N / L)$, $\ln \left(R / A^{T} L\right)$ and $\ln (N / h L)$.
} 
limited support for semi-endogenous growth theory. On the other hand, the requirement of Schumpeterian growth theory that research intensity is $I(0)$ is supported in 16 of the 20 cases. The unit root test results are generally in line with the graphical evidence. ${ }^{5}$

Table 1: Unit root tests for the second-generation endogenous growth models

\begin{tabular}{|c|c|c|c|c|c|}
\hline & $\begin{array}{l}\text { Levin, Lin and } \\
\text { Chu }(L L C)\end{array}$ & Breitung & $\begin{array}{l}\text { Im, Pesaran } \\
\text { and Shin } \\
(I P S)\end{array}$ & $\begin{array}{l}\text { Maddala and } \\
\mathrm{Wu}(M W)\end{array}$ & Choi \\
\hline & \multicolumn{5}{|c|}{ Semi-endogenous growth theory } \\
\hline $\ln A_{i t}^{T}$ & $I(0)$ & $I(1)$ & $I(1)$ & $I(1)$ & $I(1)$ \\
\hline $\ln R_{i t}$ & $I(0)$ & $I(1)$ & $I(0)$ & $I(0)$ & $I(0)$ \\
\hline \multirow[t]{2}{*}{$\ln N_{i t}$} & $I(0)$ & $I(1)$ & $I(1)$ & $I(0)$ & $I(0)$ \\
\hline & \multicolumn{5}{|c|}{ Schumpeterian growth theory } \\
\hline $\ln (R / Y)_{i t}$ & $I(0)$ & $I(0)$ & $I(0)$ & $I(0)$ & $I(0)$ \\
\hline $\ln \left(R / A^{T} L\right)_{i t}$ & $I(0)$ & $I(1)$ & $I(1)$ & $I(0)$ & $I(0)$ \\
\hline $\ln (N / L)_{i t}$ & $I(0)$ & $I(1)$ & $I(0)$ & $I(0)$ & $I(0)$ \\
\hline $\ln (N / h L)_{i t}$ & $I(0)$ & $I(1)$ & $I(0)$ & $I(0)$ & $I(0)$ \\
\hline
\end{tabular}

Notes: a trend term is included in the unit root tests for $\ln A^{T}, \ln R$ and $\ln N$ following the prediction of semiendogenous growth theory. The Breitung test includes a trend term (as required), while all the other unit root tests performed for research intensity do not include a trend term, as suggested by the Schumpeterian growth models. The integration tests are based on the 10\% decision rule. For the $L L C$, Breitung, IPS and $M W$ tests, AIC is used as the autocorrelation correction method by allowing for a maximum lag length of six. The Barlett kernel is used as the spectral estimation method for both the $L L C$ and Choi tests.

\subsection{Cointegration Analysis}

We consider the panel cointegration tests of Kao (1999) and Pedroni (2004). Semi-endogenous growth theory predicts cointegration between $\ln A^{T}$ and $\ln R$ and between $\ln A^{T}$ and $\ln N$ (see Eq. (4)). The results, which are reported in the upper part of Table 2, provide little support for semi-endogenous growth theory. In five out of seven cases, Pedroni's statistics provide no evidence of cointegration between $\ln A^{T}$ and $\ln R$ as well as $\ln A^{T}$ and $\ln N$. Evidence of cointegration is also rejected by Kao's statistics. Similarly, the error-correction terms associated with the cointegrating vector (last column) are statistically insignificant at conventional levels; thus providing further evidence against semiendogenous growth theory.

\footnotetext{
${ }^{5}$ Using the 5 percent decision rule does not alter the conclusions on the order of integration in any significant way.
} 
Table 2: Cointegration tests for the second-generation endogenous growth models

\begin{tabular}{|c|c|c|c|c|c|c|c|}
\hline Model & & \multicolumn{2}{|c|}{$\begin{array}{l}\text { Pedroni's } \\
\text { panel statistic }\end{array}$} & \multicolumn{2}{|c|}{$\begin{array}{l}\text { Pedroni's group } \\
\text { panel statistic }\end{array}$} & $\begin{array}{l}\text { Kao's } \\
\text { ADF } \\
\text { statistic }\end{array}$ & $\begin{array}{l}\text { Cointegrating } \\
\text { vector }\end{array}$ \\
\hline \multicolumn{8}{|c|}{ Semi-endogenous growth theory (Eq. (4)) } \\
\hline \multirow{4}{*}{$\ln A_{i t}^{T}$ and $\ln R_{i t}$} & $v$ & -1.127 & $(0.211)$ & - & - & \multirow{4}{*}{$\begin{array}{l}0.181 \\
(0.428)\end{array}$} & \multirow{4}{*}{$\begin{array}{rr}1.000 & -0.194 \\
& {[-2.472]} \\
\text { ect }= & -0.003 \\
& {[-1.347]}\end{array}$} \\
\hline & rho & -0.226 & $(0.389)$ & -0.048 & $(0.399)$ & & \\
\hline & $P P$ & -0.758 & $(0.299)$ & -0.784 & $(0.294)$ & & \\
\hline & $A D F$ & 3.174 & $(0.003)$ & 2.503 & $(0.017)$ & & \\
\hline \multirow{4}{*}{$\ln A_{i t}^{T}$ and $\ln N_{i t}$} & $v$ & -1.414 & $(0.147)$ & - & - & \multirow{4}{*}{$\begin{array}{l}-0.116 \\
(0.454)\end{array}$} & \multirow{4}{*}{$\begin{aligned} 1.000 & -0.673 \\
& {[-4.739] } \\
e c t= & -0.002 \\
& {[-1.377] }\end{aligned}$} \\
\hline & rho & 1.118 & $(0.214)$ & -0.286 & $(0.383)$ & & \\
\hline & $P P$ & 1.010 & $(0.240)$ & -0.756 & $(0.300)$ & & \\
\hline & $A D F$ & 5.634 & $(0.000)$ & 4.989 & $(0.000)$ & & \\
\hline \multicolumn{8}{|c|}{ Schumpeterian growth theory (Eq. (5)) } \\
\hline \multirow{4}{*}{$\ln R_{i t}$ and $\ln Y_{i t}$} & $v$ & 1.818 & $(0.076)$ & - & - & \multirow{4}{*}{$\begin{array}{l}-1.700 \\
(0.045)\end{array}$} & \multirow{4}{*}{$\begin{aligned} 1.000 & -1.093 \\
& {[-27.838] } \\
e c t= & -0.036 \\
& {[-3.643] }\end{aligned}$} \\
\hline & rho & -2.415 & $(0.022)$ & -0.133 & $(0.395)$ & & \\
\hline & $P P$ & -4.944 & $(0.000)$ & -2.307 & $(0.028)$ & & \\
\hline & $A D F$ & 4.032 & $(0.000)$ & 6.937 & $(0.000)$ & & \\
\hline \multirow{4}{*}{$\ln R_{i t}$ and $\ln A^{T} L_{i t}$} & $v$ & 2.381 & $(0.023)$ & - & - & \multirow{4}{*}{$\begin{array}{l}-2.328 \\
(0.010)\end{array}$} & \multirow{4}{*}{$\begin{array}{ll}1.000 & -0.247 \\
& {[-2.755]} \\
e c t= & -0.005 \\
& {[-1.877]}\end{array}$} \\
\hline & rho & -2.648 & $(0.012)$ & -1.043 & $(0.232)$ & & \\
\hline & $P P$ & -5.089 & $(0.000)$ & -3.400 & $(0.001)$ & & \\
\hline & $A D F$ & 4.836 & $(0.000)$ & 5.740 & $(0.000)$ & & \\
\hline \multirow{4}{*}{$\ln N_{i t}$ and $\ln L_{i t}$} & $v$ & 1.696 & $(0.095)$ & - & - & \multirow{4}{*}{$\begin{array}{l}-2.228 \\
(0.013)\end{array}$} & \multirow{4}{*}{$\begin{aligned} 1.000 & -0.753 \\
& {[-4.706] } \\
\text { ect }= & -0.011 \\
& {[-3.704] }\end{aligned}$} \\
\hline & rho & -1.357 & $(0.159)$ & -0.245 & $(0.387)$ & & \\
\hline & $P P$ & -2.742 & $(0.009)$ & -1.545 & $(0.121)$ & & \\
\hline & $A D F$ & 1.926 & $(0.063)$ & 3.364 & $(0.001)$ & & \\
\hline \multirow{4}{*}{$\ln N_{i t}$ and $\ln h L_{i t}$} & $v$ & 1.002 & $(0.242)$ & - & - & \multirow{4}{*}{$\begin{array}{l}-1.266 \\
(0.103)\end{array}$} & \multirow{4}{*}{$\begin{aligned} 1.000 & -0.537 \\
& {[-3.712] } \\
e c t= & -0.011 \\
& {[-3.755] }\end{aligned}$} \\
\hline & rho & -1.128 & $(0.211)$ & -0.119 & $(0.396)$ & & \\
\hline & $P P$ & -2.352 & $(0.025)$ & -1.593 & $(0.112)$ & & \\
\hline & $A D F$ & 3.664 & $(0.001)$ & 6.277 & $(0.000)$ & & \\
\hline
\end{tabular}

Notes: an intercept, but no trend, is included in all estimations. The optimal lag length is based on the AIC criterion by allowing for a maximum of six lags. Cointegration tests are performed under the null of no cointegration where the Barlett kernel method is used in spectral estimation and the bandwidth is based on the Newey-West procedure. The cointegrating vectors are estimated under the panel VECM framework. ect is the coefficient of the error-correction term. Numbers in the round parenthesis are $p$-values and figures in square brackets are $t$-statistics.

Schumpeterian growth theories predict that $R \& D$ should be cointegrated with various measures of product variety (see Eq. (5)). The cointegration tests in the lower part of Table 2 are broadly in line 
with this prediction. Specifically, there is strong evidence of cointegration between $\ln R$ and $\ln Y, \ln R$ and $\ln \left(A^{T} L\right)$ and $\ln N$ and $\ln L$. There is less evidence of cointegration between $\ln N$ and $\ln (h L)$. They are cointegrated in only three out of the seven cases. It is important to note that the second elements in the cointegrating vectors are both economically and statistically significant, as predicted by the theory. Moreover, the error-correction terms are statistically significant in all cases, providing further supporting evidence for cointegration. However, there is no clear one-to-one relationship between the variables in all cases, as predicted by the theory. We therefore impose the restriction of $(1-1)$ on the elements of the cointegrating vector. Based on the likelihood ratio tests, this restriction cannot be rejected at the $5 \%$ significance level, except for one case in which the VECM involves $\ln N$ and $\ln (h L)$ (results are not shown). These tests suggest that the coefficients of the cointegration vectors are in the ranges predicted by Schumpeterian theory.

\subsection{TFP growth estimates}

The TFP growth equation given by Eq. (6) is estimated to shed further light on the secondgeneration growth models and to examine the role played by $\mathrm{R} \& \mathrm{D}$ in explaining growth in the six Asian countries considered here. The model is estimated using the SUR approach in which the covariance structure allows for conditional correlation between the contemporaneous errors across countries. Country and time dummies are included in the regressions. The exclusion of these dummies does not change the results in any significant manner. The regressions are performed in 5-year differences to filter out the influence of business cycle influences and transitional dynamics on the estimates. Variables in levels are measured as 5-year moving averages (ranging over the time-span of the first-differences).

Columns 1 and 2 in Table 3 show the regression results related to semi-endogenous growth theory. The results are consistent with the predictions of semi-endogenous growth theory when research inputs are measured by $R \& D$ expenditures but not when $R \& D$ is measured by the number of $R \& D$ workers. For estimates relating to Schumpeterian growth theory, the regressions give support for the theory in all four cases, regardless of how research intensity is measured (columns 3-6). The results are almost identical when the two theories are combined in an integrated framework (columns 7-10).

The results have important implications for economic growth and endogenous growth theories. In the regressions where both $\mathrm{R} \& \mathrm{D}$ growth and research intensity are significant, or where only research intensity is significant, growth is governed by research intensity in the long run. An R\&Dinduced increase in research intensity leads to TFP growth in the short and medium run that exceeds the steady-state TFP growth due to the growth effects of R\&D. TFP growth is kept at a constant rate 
that is driven by research intensity in the steady state. Growth in that sense is Schumpeterian, and not semi-endogenous, along the balanced growth path.

Table 3: Productivity Growth Regressions (5-year estimates) (Eq. (6))

\begin{tabular}{|c|c|c|c|c|c|c|c|c|c|c|}
\hline & \multicolumn{2}{|c|}{$\begin{array}{l}\text { Semi- } \\
\text { endogenous }\end{array}$} & \multicolumn{2}{|c|}{$\underline{\text { Schumpeterian }}$} & \multirow[b]{2}{*}{ (5) } & \multirow[b]{2}{*}{ (6) } & \multicolumn{2}{|c|}{$\underline{\text { Both models }}$} & \multirow[b]{2}{*}{ (9) } & \multirow[b]{2}{*}{ (10) } \\
\hline & (1) & $(2)$ & (3) & (4) & & & (7) & (8) & & \\
\hline Intercept & $\begin{array}{l}3.95 \\
(0.11)\end{array}$ & $\begin{array}{l}7.83^{* * *} \\
(0.00)\end{array}$ & $\begin{array}{l}20.63^{* * *} \\
(0.00)\end{array}$ & $\begin{array}{l}9.23^{* * *} \\
(0.00)\end{array}$ & $\begin{array}{l}16.62^{* * *} \\
(0.00)\end{array}$ & $\begin{array}{l}17.17^{* * * *} \\
(0.00)\end{array}$ & $\begin{array}{l}21.73^{* * *} \\
(0.00)\end{array}$ & $\begin{array}{l}6.01^{* * *} \\
(0.00)\end{array}$ & $\begin{array}{l}19.62^{* * *} \\
(0.00)\end{array}$ & $\begin{array}{l}18.97^{* * * *} \\
(0.00)\end{array}$ \\
\hline$\Delta \ln R_{i t}$ & $\begin{array}{l}0.08^{* * *} \\
(0.00)\end{array}$ & & & & & & $\begin{array}{l}0.07^{* *} \\
(0.03)\end{array}$ & $\begin{array}{l}0.08^{* * *} \\
(0.00)\end{array}$ & & \\
\hline$\Delta \ln N_{i t}$ & & $\begin{array}{l}0.05 \\
(0.11)\end{array}$ & & & & & & & $\begin{array}{l}0.04^{*} \\
(0.07)\end{array}$ & $\begin{array}{l}0.03 \\
(0.15)\end{array}$ \\
\hline $\ln (R / Y)_{i t}$ & & & $\begin{array}{l}2.43^{* *} \\
(0.02)\end{array}$ & & & & $\begin{array}{l}2.97^{* *} \\
(0.03)\end{array}$ & & & \\
\hline $\ln \left(R / A^{T} L\right)_{i t}$ & & & & $\begin{array}{l}1.33^{* *} \\
(0.02)\end{array}$ & & & & $\begin{array}{l}1.63^{* * *} \\
(0.00)\end{array}$ & & \\
\hline $\ln (N / L)_{i t}$ & & & & & $\begin{array}{l}1.93^{* * *} \\
(0.00)\end{array}$ & & & & $\begin{array}{l}2.37^{* * *} \\
(0.00)\end{array}$ & \\
\hline $\ln (N / h L)_{i t}$ & & & & & & $\begin{array}{l}1.38^{* * *} \\
(0.00)\end{array}$ & & & & $\begin{array}{l}1.46^{* * *} \\
(0.00)\end{array}$ \\
\hline
\end{tabular}

Notes: country and time dummies are not reported to conserve space. The numbers in parentheses are $p$-values. Variables in first-differenced form provide estimates in five-year differences whereas those in levels give five-year moving averages. *, $* *$ and $* * *$ signify $10 \%, 5 \%$ and $1 \%$ levels of significance, respectively.

\subsection{Ideas production estimates}

Annual and five-year interval estimates of the ideas production functions in Eqs. (7) and (8) are reported in Table 4. The model is estimated using the same approach as above. Country and time dummies are also included in the regressions. Considering the semi-endogenous growth models, the coefficients of R\&D are either statistically insignificant or significant but have the sign opposite to the theoretical prediction, regardless of whether $R \& D$ input is measured by the number of $R \& D$ workers or by $R \& D$ expenditure and regardless of whether annual or five-year data are used (columns 1 and 3 ). These results are also inconsistent with the predictions of the first-generation endogenous growth models even if there may be a scale effect in ideas production. On the other hand, there is very strong evidence in favour of Schumpeterian growth theory. The coefficients of research intensity are statistically and economically significant in all regressions (columns 2 and 3). Furthermore, the coefficients of knowledge stock $(A)$ are also highly significant and remarkably close to the prediction of one by Schumpeterian growth models. The null hypothesis of the presence of scale effects in 
knowledge production $\left(\gamma_{2}=1\right.$ in Eq. 8$)$ cannot be rejected at conventional levels of significance in any of the cases, as indicated by the Wald test results.

Table 4: Annual (1953-06) and 5-year (1955-05) estimates of ideas production functions (Eqs. 7 \& 8)

\begin{tabular}{|c|c|c|c|c|c|c|c|c|c|c|}
\hline & \multicolumn{2}{|c|}{$\begin{array}{l}\text { Semi- } \\
\text { endogenous }\end{array}$} & \multicolumn{2}{|c|}{$\underline{\text { Schumpeterian }}$} & \multicolumn{2}{|c|}{$\underline{\text { Schumpeterian }}$} & \multicolumn{2}{|c|}{$\underline{\text { Both models }}$} & \multicolumn{2}{|c|}{$\underline{\text { Both models }}$} \\
\hline & $\frac{\text { Annual }}{(1 \mathrm{a})}$ & $\frac{5 \text {-year }}{(1 b)}$ & $\frac{\text { Annual }}{(2 a)}$ & $\frac{5 \text {-year }}{(2 b)}$ & $\frac{\text { Annual }}{(2 \mathrm{c})}$ & $\frac{5 \text {-year }}{(2 d)}$ & $\frac{\text { Annual }}{(3 a)}$ & $\frac{5 \text {-year }}{(3 b)}$ & $\frac{\text { Annual }}{(3 c)}$ & $\frac{5 \text {-year }}{(3 d)}$ \\
\hline & \multicolumn{10}{|c|}{ (A) R\&D input is measured by $R \& D$ expenditure } \\
\hline $\ln R_{i t}$ & $\begin{array}{l}-0.022^{+} \\
(0.046)\end{array}$ & $\begin{array}{l}-0.022 \\
(0.264)\end{array}$ & & & & & $\begin{array}{l}-0.064^{+} \\
(0.011)\end{array}$ & $\begin{array}{l}-0.036 \\
(0.170)\end{array}$ & $\begin{array}{l}0.009 \\
(0.485)\end{array}$ & $\begin{array}{l}0.025 \\
(0.273)\end{array}$ \\
\hline $\ln (R / Y)_{i t}$ & & & $\begin{array}{l}0.031^{+} \\
(0.037)\end{array}$ & $\begin{array}{l}0.073^{+} \\
(0.012)\end{array}$ & & & $\begin{array}{l}0.062^{+} \\
(0.041)\end{array}$ & $\begin{array}{l}0.103^{\#} \\
(0.007)\end{array}$ & & \\
\hline $\ln \left(R / A^{I} L\right)_{i t}$ & & & & & $\begin{array}{l}0.025^{\#} \\
(0.000)\end{array}$ & $\begin{array}{l}0.029^{+} \\
(0.037)\end{array}$ & & & $\begin{array}{l}0.018^{+} \\
(0.039)\end{array}$ & $\begin{array}{l}0.027^{+} \\
(0.037)\end{array}$ \\
\hline $\ln A_{i t}^{I}$ & $\begin{array}{l}0.987^{\#} \\
(0.000)\end{array}$ & $\begin{array}{l}0.995^{\#} \\
(0.000)\end{array}$ & $\begin{array}{l}0.988^{\#} \\
(0.000)\end{array}$ & $\begin{array}{l}1.009^{\#} \\
(0.000)\end{array}$ & $\begin{array}{l}1.002^{\#} \\
(0.000)\end{array}$ & $\begin{array}{l}1.020^{\#} \\
(0.000)\end{array}$ & $\begin{array}{l}1.009^{\#} \\
(0.000)\end{array}$ & $\begin{array}{l}1.017^{\#} \\
(0.000)\end{array}$ & $\begin{array}{l}1.007^{\#} \\
(0.000)\end{array}$ & $\begin{array}{l}1.004^{\#} \\
(0.000)\end{array}$ \\
\hline \multirow[t]{2}{*}{$\chi_{\text {Wald }}^{2}$} & $\begin{array}{l}1.569 \\
(0.210)\end{array}$ & $\begin{array}{l}0.215 \\
(0.643) \\
\end{array}$ & $\begin{array}{l}2.481 \\
(0.115) \\
\end{array}$ & $\begin{array}{l}1.151 \\
(0.283) \\
\end{array}$ & $\begin{array}{l}0.118 \\
(0.731) \\
\end{array}$ & $\begin{array}{l}2.409 \\
(0.121)\end{array}$ & $\begin{array}{l}0.298 \\
(0.585)\end{array}$ & $\begin{array}{l}0.869 \\
(0.351) \\
\end{array}$ & $\begin{array}{l}0.298 \\
(0.585) \\
\end{array}$ & $\begin{array}{l}0.047 \\
(0.828) \\
\end{array}$ \\
\hline & \multicolumn{10}{|c|}{ (B) $\mathrm{R} \& \mathrm{D}$ input is measured by $\mathrm{R} \& \mathrm{D}$ workers } \\
\hline $\ln N_{i t}$ & $\begin{array}{l}-0.031^{+} \\
(0.035)\end{array}$ & $\begin{array}{l}-0.016 \\
(0.439)\end{array}$ & & & & & $\begin{array}{l}-0.066^{\#} \\
(0.001)\end{array}$ & $\begin{array}{l}-0.309^{+} \\
(0.064)\end{array}$ & $\begin{array}{l}-0.106^{\#} \\
(0.001)\end{array}$ & $\begin{array}{l}-0.054 \\
(0.251)\end{array}$ \\
\hline $\ln (N / L)_{i t}$ & & & $\begin{array}{l}0.039^{+} \\
(0.018)\end{array}$ & $\begin{array}{l}0.062^{+} \\
(0.021)\end{array}$ & & & $\begin{array}{l}0.104^{\#} \\
(0.000)\end{array}$ & $\begin{array}{l}0.425^{+} \\
(0.033)\end{array}$ & & \\
\hline $\ln (N / h L)_{i t}$ & & & & & $\begin{array}{l}0.049^{\#} \\
(0.004)\end{array}$ & $\begin{array}{l}0.075^{\#} \\
(0.009)\end{array}$ & & & $\begin{array}{l}0.136^{\#} \\
(0.000)\end{array}$ & $\begin{array}{l}0.132^{+} \\
(0.023)\end{array}$ \\
\hline $\ln A_{i t}^{I}$ & $\begin{array}{l}1.001^{\#} \\
(0.000)\end{array}$ & $\begin{array}{l}0.986^{\#} \\
(0.000)\end{array}$ & $\begin{array}{l}0.998^{\#} \\
(0.000)\end{array}$ & $\begin{array}{l}0.987^{\#} \\
(0.000)\end{array}$ & $\begin{array}{l}0.992^{\#} \\
(0.000)\end{array}$ & $\begin{array}{l}0.993^{\#} \\
(0.000)\end{array}$ & $\begin{array}{l}0.987^{\#} \\
(0.000)\end{array}$ & $\begin{array}{l}1.006^{\#} \\
(0.000)\end{array}$ & $\begin{array}{l}1.016^{\#} \\
(0.000)\end{array}$ & $\begin{array}{l}0.998^{\#} \\
(0.000)\end{array}$ \\
\hline$\chi_{\text {Wald }}^{2}$ & $\begin{array}{l}0.001 \\
(0.973)\end{array}$ & $\begin{array}{l}1.876 \\
(0.171)\end{array}$ & $\begin{array}{l}0.023 \\
(0.879)\end{array}$ & $\begin{array}{l}0.803 \\
(0.371)\end{array}$ & $\begin{array}{l}0.741 \\
(0.389)\end{array}$ & $\begin{array}{l}0.356 \\
(0.551)\end{array}$ & $\begin{array}{l}1.050 \\
(0.305)\end{array}$ & $\begin{array}{l}0.072 \\
(0.789)\end{array}$ & $\begin{array}{l}1.148 \\
(0.284)\end{array}$ & $\begin{array}{l}0.002 \\
(0.962)\end{array}$ \\
\hline
\end{tabular}

Notes: the intercept, country and time dummies are not reported to conserve space. The numbers in parentheses are standard errors. $\chi_{\text {Wald }}^{2}$ is the Wald statistic. The Wald test restricts the coefficient of $\ln A_{i t}$ to be one under null where a non-rejection of the null indicates the presence of scale effects in ideas production functions. + and \# indicate $5 \%$ and $1 \%$ levels of significance, respectively.

The estimates of ideas production functions give some important insights into growth dynamics in the Asian miracle economies. The findings of constant returns to knowledge production not only imply significant positive intertemporal knowledge spillovers but also that there are permanent growth effects of research intensity. Furthermore, the coefficients of research intensity are in their predicted range and indicate that some innovations are truly novel whereas others are duplications, noting that the closer the coefficient of research intensity is to zero the larger is the fraction of R\&D intensity that is allocated towards duplication. 


\section{Robustness Checks and the Asian Growth Miracle}

The results so far give very strong support for Schumpeterian growth theory and suggest that $R \& D$ has played an important role for growth in the Asian miracle economies. This section goes further by investigating factors in addition to $\mathrm{R} \& \mathrm{D}$ that may have been important for growth in these economies and checks whether the estimates are robust to the consideration of alternative estimation periods and ten-year intervals. Distance to the technological frontier, trade openness and international knowledge spillovers are included as control variables in the growth equations because they play an important role according to the theories of economic growth and development. The robustness checks are carried out for both the TFP growth and ideas production equations. The growth in physical capital stock $\left(\triangle \ln K A P_{i t}\right)$ is included as an additional regressor in the TFP growth regressions to cater for transitional dynamics.

According to Howitt (2000), Griffith et al. (2003) and Ha et al. (2009), distance to the technological frontier is important for growth as the effective costs of innovations are lower the further away a country is from the frontier. Aghion et al. (2005), Acemoglu et al. (2006), Aghion and Howitt (2009, Ch. 7) show that technology transfer allows countries that are behind the frontier to grow at a higher rate than otherwise. Following the convention, distance to the frontier is measured as $A_{t}^{T-U S} / A^{T}{ }_{i t}$, where $A_{t}^{T-U S}$ is the TFP level for the U.S. in the TFP growth regressions. In ideas production equations, DTF is measured as the ratio of the frontier's stock of patents $\left(A_{t}^{I-\text { frontier }}\right)$ to the domestic stock of patents $\left(A_{i t}^{I}\right)$, where the frontier is the country with the highest accumulation of patents at time $t$.

Trade openness is expected to impact positively on TFP growth, according to the literature on trade and development. This strand of literature considers exports as growth-enhancing because of the positive productivity spillovers from the tradable to the non-tradable sector; thus encouraging more efficient investment projects (Edwards, 1998). Growth rather than levels of trade openness is included in the regressions since the coefficients of the logs of trade openness were consistently insignificant. The absence of a level effect of trade openness is perhaps not surprising since a permanent increase in the efficiency of production is necessary for trade openness to have permanent growth effects. 
Table 5: TFP Growth and Ideas Production Regressions with Control Variables (5-year estimates)

\begin{tabular}{|c|c|c|c|c|c|c|c|c|c|c|}
\hline & \multicolumn{2}{|c|}{$\begin{array}{l}\text { Semi- } \\
\text { endogenous }\end{array}$} & \multicolumn{2}{|c|}{$\underline{\text { Schumpeterian }}$} & \multicolumn{2}{|c|}{$\underline{\text { Schumpeterian }}$} & \multicolumn{2}{|c|}{$\underline{\text { Both models }}$} & \multicolumn{2}{|c|}{$\underline{\text { Both models }}$} \\
\hline & (1a) & $(1 \mathrm{~b})$ & (2a) & $(2 b)$ & $(2 \mathrm{c})$ & $(2 \mathrm{~d})$ & (3a) & $(3 b)$ & $(3 \mathrm{c})$ & (3d) \\
\hline & \multicolumn{10}{|c|}{ (A) Productivity growth estimates (Eq. 6) $\left(\right.$ Dep. var. $\left.=\Delta \ln A^{T}\right)$} \\
\hline$\Delta \ln R_{i t}$ & $0.098^{\#}$ & & & & & & $0.088^{\#}$ & $0.092^{\#}$ & & \\
\hline$\Delta \ln N_{i t}$ & & $0.056^{+}$ & & & & & & & $0.052^{+}$ & 0.028 \\
\hline $\ln (R / Y)_{i t}$ & & & $2.330^{+}$ & & & & $2.661^{\#}$ & & & \\
\hline $\ln \left(R / A^{T} L\right)_{i t}$ & & & & $2.140^{\#}$ & & & & $2.375^{\#}$ & & \\
\hline $\ln (N / L)_{i t}$ & & & & & $1.833^{\#}$ & & & & $2.488^{\#}$ & \\
\hline $\ln (N / h L)_{i t}$ & & & & & & $1.443^{+}$ & & & & $1.354^{+}$ \\
\hline $\ln D T F_{i t}$ & $11.372^{*}$ & 0.542 & $5.840^{\#}$ & $8.562^{\#}$ & 1.804 & $4.086^{*}$ & 1.047 & $4.918^{*}$ & $6.420^{+}$ & $4.711^{+}$ \\
\hline$\Delta \ln T O_{i t}$ & $0.067^{\#}$ & $0.068^{\#}$ & $0.056^{\#}$ & $0.046^{+}$ & 0.006 & $0.059^{\#}$ & $0.067^{\#}$ & $0.066^{\#}$ & $0.024^{*}$ & $0.035^{+}$ \\
\hline$\Delta\left(m_{i t} \ln S_{i t}^{F}\right)$ & $0.008^{*}$ & 0.001 & 0.005 & 0.007 & $0.010^{+}$ & 0.006 & $0.009^{*}$ & $0.011^{+}$ & 0.006 & 0.006 \\
\hline \multirow[t]{2}{*}{$\Delta \ln K A P_{i t}$} & $-6.313^{+}$ & $-7.615^{+}$ & -1.130 & -1.224 & -4.458 & -3.857 & -5.426 & $-6.269^{*}$ & -4.591 & $-6.332^{*}$ \\
\hline & \multicolumn{10}{|c|}{ (B) Ideas production estimates (Eqs. (7) and (8)) (Dep. var. $=\ln \dot{A}^{I}$ ) } \\
\hline $\ln R_{i t}$ & -0.001 & & & & & & $-0.091^{+}$ & $0.087^{\#}$ & & \\
\hline $\ln N_{i t}$ & & 0.006 & & & & & & & $-0.364^{\#}$ & $-0.139^{\ddagger}$ \\
\hline $\ln (R / Y)_{i t}$ & & & $0.060^{+}$ & & & & $0.166^{\#}$ & & & \\
\hline $\ln \left(R / A^{I} L\right)_{i t}$ & & & & $0.034^{+}$ & & & & $0.058^{+}$ & & \\
\hline $\ln (N / L)_{i t}$ & & & & & $0.090^{+}$ & & & & $0.471^{\#}$ & \\
\hline $\ln (N / h L)_{i t}$ & & & & & & $0.076^{+}$ & & & & $0.228^{\#}$ \\
\hline $\ln A_{i t}^{I}$ & $0.996^{\#}$ & $0.993^{\#}$ & $1.013^{\#}$ & $1.012^{\#}$ & $1.023^{\#}$ & $1.021^{\#}$ & $1.037^{\#}$ & $0.996^{\#}$ & $1.018^{\#}$ & $1.028^{\#}$ \\
\hline $\ln D T F_{i t}$ & $0.225^{\#}$ & $0.234^{\#}$ & 0.089 & $0.307^{\#}$ & -0.028 & 0.111 & 0.022 & $0.294^{\#}$ & $0.309^{\#}$ & $0.296^{\#}$ \\
\hline$\Delta \ln T O_{i t}$ & 0.001 & 0.001 & $0.001^{*}$ & $0.001^{+}$ & 0.001 & 0.001 & 0.001 & 0.000 & 0.001 & $0.002^{+}$ \\
\hline$\Delta\left(m_{i t} \ln S_{i t}^{F}\right)$ & 0.001 & 0.001 & 0.001 & 0.001 & 0.001 & 0.001 & 0.001 & $-0.001^{\#}$ & 0.001 & $-0.001^{\dagger}$ \\
\hline$\chi_{\text {Wald }}^{2}$ & $\begin{array}{l}0.036 \\
(0.850)\end{array}$ & $\begin{array}{l}0.090 \\
(0.764)\end{array}$ & $\begin{array}{l}2.176 \\
(0.140)\end{array}$ & $\begin{array}{l}0.994 \\
(0.331)\end{array}$ & $\begin{array}{l}1.398 \\
(0.237)\end{array}$ & $\begin{array}{l}1.432 \\
(0.231)\end{array}$ & $\begin{array}{l}2.313 \\
(0.128)\end{array}$ & $\begin{array}{l}0.041 \\
(0.839)\end{array}$ & $\begin{array}{l}0.537 \\
(0.464)\end{array}$ & $\begin{array}{l}1.136 \\
(0.287)\end{array}$ \\
\hline
\end{tabular}

Notes: the intercept, country and time dummies are included in the estimates but are not reported. DTF = distance to frontier, $T O=$ trade openness, $K A P=$ capital stock, $m=$ propensity to import, and $S^{F}=$ stock of foreign capital. Variables in first-differenced form provide estimates in five-year differences whereas those in levels give five-year averages. $\chi_{\text {Wald }}^{2}$ is the Wald statistic of scale effects in ideas production. The numbers in parentheses are $p$-values. *, + and \# indicate $10 \%, 5 \%$ and $1 \%$ levels of significance, respectively.

The recent endogenous growth literature has re-orientated the growth-enhancing effects of trade openness from exports to imports of knowledge (see Romer, 1990; Grossman and Helpman, 1991; Rivera-Batiz and Romer, 1991). Romer (1990), for instance, argues that imports give domestic producers access to a wider variety of capital goods, thereby effectively enlarging the efficiency of production. The theoretical models described in Grossman and Helpman (1991) suggest that the quality 
of intermediate products positively influences the efficiency of production. The new technology embodied in imported intermediate products renders them more productive and thus increases TFP. As a consequence, trade will only enhance growth to the extent that a country trades with researchintensive economies. ${ }^{6}$

The regression results of the augmented TFP growth model and ideas production are displayed in Table 5. The coefficients of distance to the frontier $\left(\ln D T F_{i t}\right)$ are statistically significant in more than half of the cases, providing some supporting evidence for the hypothesis that the miracle economies are catching up to the technological frontier. Our results are consistent with Ha et al. (2009), who show that technology gap has a significant impact on TFP growth in the economies of Japan, Korea and Taiwan. Growth in trade openness $\left(\Delta \ln T O_{i t}\right)$ has significantly positive effects on TFP growth in most cases. However, its effect is less significant in the ideas production regressions. This is not surprising given that the creation of new ideas is not directly related to the effectiveness of production. Although this finding indicates that outward orientation may have played a potential role for TFP growth in Asia, a much more in-depth analysis of trade barriers and other discretionary trade policies is required before the outward-orientation hypothesis can be validated.

The coefficients of the growth in international knowledge spillovers $\left(\Delta m_{i t} \ln S_{i t}^{F}\right)$ are statistically significant in two-fifths of the cases in productivity growth regressions, providing some support for the proposition of Coe and Helpman (1995). These results are, to some extent, consistent with Coe et al. (1997), Lichtenberg and van Pottelsberghe de la Potterie (1998), Savvides and Zachariadis (2005) and Madsen (2007, 2008a) for the mature OECD countries. However, the estimates also suggest that imports of knowledge have been less important for growth in the Asian economies than for the mature OECD countries. Moreover, growth in international knowledge spillovers is found to be ineffective in boosting ideas production in the Asian miracles. Coupled with the findings of the significance of domestic $R \& D$, this result suggests that imports of knowledge do not play as important a role for take-off as investment in domestic R\&D.

\footnotetext{
6 International R\&D spillovers through the channel of imports $\left(m_{i t} \ln S_{i t}^{F}\right)$ are computed following the approach suggested by Lichtenberg and van Pottelsberghe de la Potterie (1998), where $m_{i t}$ is import penetration (imports over GDP) and $S_{i t}^{F}$ is foreign R\&D stock. $S_{i t}^{F}=\sum_{j=1}^{26}\left(M_{i j t} / Y_{j t}\right) S_{j t}^{D}, i \neq j$, where $M_{i j t}$ is country $i$ 's imports from the exporting country $j$ at time $t$; $Y_{j t}$ is exporter $j$ 's GDP at time $t$; and $S_{j t}^{D}$ is exporter $j$ 's R\&D capital stock at time $t . S_{j t}^{D}$ is based on R\&D in 20 OECD countries and the six Asian countries considered in the study (excluding country $i$ 's own R\&D stock).
} 
Importantly, the key findings in the previous section are not overturned by the inclusion of the control variables. Consider first the estimates of the productivity growth equation in the upper half of Table 5. The coefficients of the growth in $R \& D$ expenditures or the number of $R \& D$ workers are significantly positive in most cases. Furthermore, the coefficients of research intensity are highly significant in all cases, suggesting that the significance of $R \& D$ growth is not implying that growth is semi-endogenous but rather that the estimates have been influenced by transitional dynamics. This conclusion is reinforced by the fact that the coefficients of levels $R \& D$ are insignificant in the regressions of ideas production functions (panel $\mathrm{B}$ in Table 5). The estimates of ideas production functions give even stronger support in favor of the Schumpeterian growth theory. All coefficients of research intensity are highly significant and the coefficients of knowledge production are also very close to one. The null hypothesis of the presence of scale effects in ideas production cannot be rejected at the conventional levels, as indicated by the Wald test results in the table.

Table 6: Alternative Sample Periods for Productivity Growth Regressions (5-year estimates)

\begin{tabular}{|c|c|c|c|c|c|c|c|c|c|c|c|c|}
\hline \multirow[b]{4}{*}{$\Delta \ln R_{i t}$} & \multicolumn{4}{|c|}{ Period: 1966-2005 } & \multicolumn{4}{|c|}{ Period: $1971-2005$} & \multicolumn{4}{|c|}{ Period: $1976-2005$} \\
\hline & (1a) & $(1 b)$ & $(1 \mathrm{c})$ & $(1 \mathrm{~d})$ & $(2 a)$ & $(2 b)$ & $(2 \mathrm{c})$ & $(2 d)$ & (3a) & $(3 b)$ & $(3 c)$ & $(3 \mathrm{~d})$ \\
\hline & \multicolumn{12}{|c|}{ (A) Productivity growth estimates (Eq. 6) ( Dep. $=\Delta \ln A^{T}$ ) } \\
\hline & $0.08^{+}$ & $0.09^{\#}$ & & & $0.07^{*}$ & $0.08^{+}$ & & & $0.11^{\#}$ & $0.12^{\#}$ & & \\
\hline$\Delta \ln N_{i t}$ & & & $0.09^{\#}$ & $0.08^{\#}$ & & & $0.14^{\#}$ & $0.14^{\#}$ & & & $0.21^{\#}$ & $0.18^{\#}$ \\
\hline $\ln (R / Y)_{i t}$ & $2.32^{+}$ & & & & $3.60^{+}$ & & & & $3.21^{\#}$ & & & \\
\hline $\ln \left(R / A^{T} L\right)_{i t}$ & & $1.71^{\#}$ & & & & $4.34^{\#}$ & & & & $1.68^{\#}$ & & \\
\hline $\ln (N / L)_{i t}$ & & & $3.11^{\#}$ & & & & $4.21^{\#}$ & & & & $6.14^{\#}$ & \\
\hline \multirow[t]{2}{*}{$\ln (N / h L)_{i t}$} & & & & $3.06^{\#}$ & & & & $4.42^{\#}$ & & & & $6.26^{\#}$ \\
\hline & \multicolumn{12}{|c|}{ (B) Ideas production estimates (Eqs. (7) and (8)) (Dep. $\left.=\ln \dot{A}^{I}\right)$} \\
\hline $\ln R_{i t}$ & 0.02 & 0.04 & & & $0.08^{*}$ & $0.15^{\#}$ & & & 0.03 & $0.09^{\#}$ & & \\
\hline $\ln N_{i t}$ & & & $-0.37^{\#}$ & $-0.16^{+}$ & & & -0.21 & $-0.11^{*}$ & & & $-0.14^{+}$ & -0.11 \\
\hline $\ln (R / Y)_{i t}$ & $0.25^{\#}$ & & & & $0.38^{\#}$ & & & & $0.25^{\#}$ & & & \\
\hline $\ln \left(R / A^{I} L\right)_{i t}$ & & $0.18^{\#}$ & & & & $0.11^{\#}$ & & & & $0.17^{\#}$ & & \\
\hline $\ln (N / L)_{i t}$ & & & $0.56^{\#}$ & & & & $0.36^{+}$ & & & & $0.28^{\#}$ & \\
\hline $\ln (N / h L)_{i t}$ & & & & $0.30^{\#}$ & & & & $0.25^{\#}$ & & & & $0.33^{\#}$ \\
\hline $\ln A_{i t}^{I}$ & $1.03^{\#}$ & $1.00^{\#}$ & $1.02^{\#}$ & $1.03^{\#}$ & $1.01^{\#}$ & $0.98^{\#}$ & $1.00^{\#}$ & $1.02^{\#}$ & $1.02^{\#}$ & $0.98^{\#}$ & $0.97^{\#}$ & $1.03^{\#}$ \\
\hline$\chi_{\text {Wald }}^{2}$ & $\begin{array}{l}1.48 \\
(0.22)\end{array}$ & $\begin{array}{l}0.01 \\
(0.93)\end{array}$ & $\begin{array}{l}0.49 \\
(0.48)\end{array}$ & $\begin{array}{l}1.01 \\
(0.32)\end{array}$ & $\begin{array}{l}0.09 \\
(0.76)\end{array}$ & $\begin{array}{l}0.71 \\
(0.39)\end{array}$ & $\begin{array}{l}0.02 \\
(0.89)\end{array}$ & $\begin{array}{l}1.19 \\
(0.27)\end{array}$ & $\begin{array}{l}0.69 \\
(0.40)\end{array}$ & $\begin{array}{l}1.14 \\
(0.29)\end{array}$ & $\begin{array}{l}2.09 \\
(0.15)\end{array}$ & $\begin{array}{l}1.47 \\
(0.23)\end{array}$ \\
\hline
\end{tabular}

Notes: the intercept, country dummies, time dummies and control variables are included in the regressions but are not shown. $\chi_{\text {Wald }}^{2}$ is the Wald statistic. ${ }^{*},+$ and \# indicate $10 \%, 5 \%$ and $1 \%$ levels of significance, respectively. 
Furthermore, changing the estimation period does not alter the conclusion, which gives some interesting insights into the growth and development of the Asian miracle economies. Table 6 reports the results of regressing the TFP growth equation (Eq. 6) and ideas production functions (Eq. 7 and 8) over the periods 1966-2005, 1971-2005 and 1976-2005. For the TFP growth regressions, the coefficients of R\&D growth and research intensity are highly statistically and economically significant, regardless of estimation period (columns 1 to 3). Again, the significance of both changes in R\&D and research intensity indicates that growth along the balanced growth path is Schumpeterian and that the growth effects of an increase in R\&D are higher in the short run than in the long run. Interestingly, the coefficients of the growth in $R \& D$ are more significant here than in the full sample period. Since TFP growth on average has been higher after 1966, 1971 and 1976 than before, this result points to the importance of transitional dynamics for growth during the growth spurts in these economies.

Table 7: TFP Growth and Ideas Production Regressions (10-year estimates)

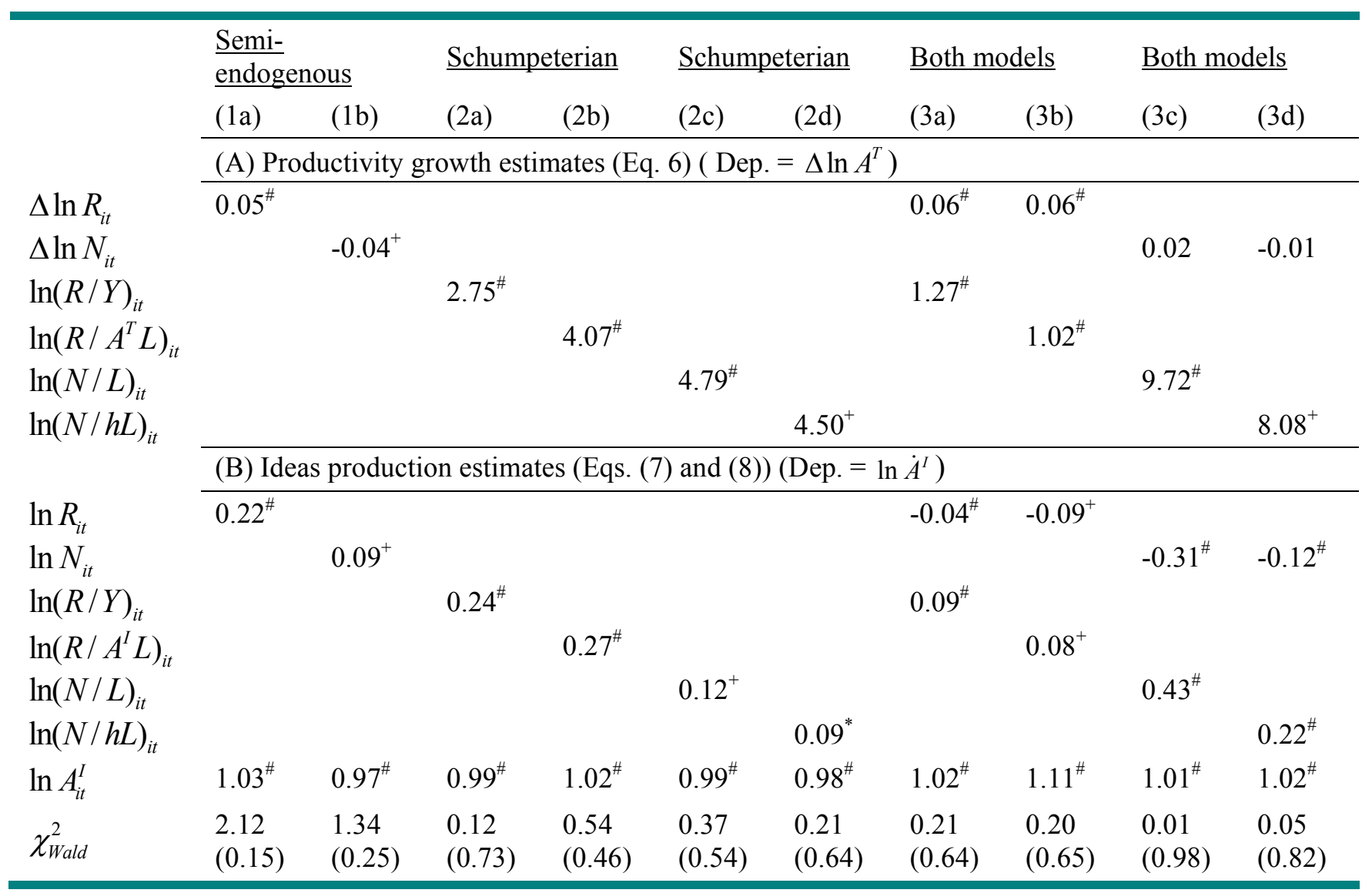

Notes: the intercept, country and time dummies are included in the estimates but are not reported to conserve space. The numbers in parentheses are $p$-values. Variables in first-differenced form provide estimates in 10 -year differences whereas those in levels give 10-year moving averages. $*,+$ and \# indicate $10 \%, 5 \%$ and $1 \%$ levels of significance, respectively. 
Finally, Table 7 displays results based on 10-year intervals. These regressions more effectively filter out the influence on the estimates of transitional dynamics and business cycles than the five-year estimates. There is again overwhelming support for Schumpeterian growth theory and only little support for semi-endogenous growth theory. The coefficients of research intensity are consistently significant while the coefficients of levels $R \& D$ or growth in $R \& D$ are only sporadically economically and statistically significant. Furthermore, the null hypothesis of the presence of scale effects in ideas production cannot be rejected at conventional significance levels in all cases.

\section{Concluding Remarks}

The spectacular growth rates experienced by some of the Asian economies in the post WWII period have often been attributed to outward orientation, market friendly policies, improved education, stable macroeconomic and political environments, etc. Thus far very little attention has been paid to the role of $R \& D$ in the context of modern endogenous growth theories. This paper turns the focus towards assessing whether the predictions of the second-generation endogenous growth models are consistent with the data and whether R\&D has been important in explaining the growth experiences of the Asian miracle economies.

The validity of the second-generation endogenous growth models in the context of the Asian miracle economies was tested using a variety of approaches, including unit root and cointegration tests, and estimation of TFP growth models and ideas production functions. The panel cointegration tests gave strong support for Schumpeterian growth theory and only limited support for semi-endogenous growth theory. These findings suggest that there is a robust long-run relationship between R\&D and product variety but not between TFP and R\&D. The results are consistent with the findings of Ha and Howitt (2007) for the US and Madsen (2008b) for mature OECD countries. The TFP growth regressions showed that $R \& D$ growth and $R \& D$ intensity have been influential for Asian growth. Estimates of ideas production functions gave strong evidence of scale effects in ideas production, suggesting the presence of strong intertemporal knowledge transfer. Coupled with the finding of consistently very significant coefficients of R\&D intensity, these results reinforced the TFP growth estimates that R\&D intensity has permanent growth effects. Since the coefficients of R\&D in ideas production functions were either insignificant or had the sign opposite to the theoretical prediction, the results gave no support for semi-endogenous growth theory. Overall the results gave very strong evidence that growth is driven by research intensity along the balanced growth path, as predicted by Schumpeterian growth theory. 
The results have important implications for future growth in the Asian miracle economies. In contrast to the dire predictions of Kim and Lau (1994), Krugman (1994) and Young $(1994,1995)$ that growth among the Four Tigers would eventually come to a halt, our results suggest that the Asian miracle economies are on a persistently positive growth path. Furthermore, the prevailing research intensities are likely to provide higher growth than the growth experienced by the industrialized countries. The coefficients of research intensity in this paper are significantly higher than those estimated for the mature industrialized countries by Zachariadis (2003), Ha and Howitt (2007) and Madsen (2008b). Together with the fact that $R \& D$ intensity of some of the countries in this study are comparable to those of the industrialized countries, this result implies that R\&D intensity has been at least as important for growth in the Asian miracles as for in the industrialized countries. The growth process is likely to slow as the Asian countries approach the technology frontier and as the momentum in R\&D growth falls. However, it will take a while for some of these countries to reach that state. While Japan has approximately reached the balanced growth path, China and India still have a long way to go.

The results not only highlight that $R \& D$ is an engine of growth but also that it plays a very important role for countries at the take-off stage. Improving the economic environment may temporarily increase production efficiency. However, for a country to be competitive in the global economy, it needs to improve the quality of its products and this requires a highly skilled labor force and significant R\&D investment. A more complex issue is how policies can foster an environment that is conducive to $R \& D$ investment. This will be left for future research. 


\section{Data Appendix}

Total factor productivity (TFP). TFP is computed as $A=Y /\left(K^{\alpha} L^{1-\alpha}\right)$, where $Y$ is real GDP, $K$ is non-residential capital stock and $L$ is employment. Capital income share $(\alpha)$ is set to 0.3 , following Aghion and Howitt (2007). The following sources are used to obtain $Y$ and $L$ : China: Wang and Yao (2003), China Statistical Yearbook (various issues) and "Comprehensive Statistical Data and Materials on 50 Years of New China", Beijing: China Statistics Press. India: National Account Statistics (various issues) and Penn World Table 6.2. Japan: Japan Statistical Yearbook (various issues). Korea: Korea Statistical Yearbook (various issues). Singapore: Yearbook of Statistics Singapore (various issues). Taiwan: Taiwan Statistical Data Book (various issues). US: Bureau of Economic Analysis (http://www.bea.gov/).

The construction of $K$ involves: (i) non-residential buildings and structures; and (ii) machinery and equipment. A depreciation rate of 3\% is assumed for the former and $17 \%$ for the latter. Investment data from the earliest available years have been used to generate the initial stock for the year 1953 (China: 1953, India: 1950, Japan: 1870, Korea: 1913, Singapore: 1956 and Taiwan: 1912). The initial capital stock is obtained by using the Solow model steady-state value of $I_{0} /(\delta+g)$, where $I_{0}$ is initial real investment, $\delta$ is the rate of depreciation and $g$ is the growth rate in real investment over the period for which investment data are first available to 2006. The breakdown of investment series for China is available only from 1981. They have been backdated using the total investment series. The following sources have been used to obtain investment: China: China Statistical Yearbook (various issues) and "Comprehensive Statistical Data and Materials on 50 Years of New China", Beijing: China Statistics Press. India: National Account Statistics (various issues). Japan: Madsen (2008b). 25.7\% war damage has been applied to the 1945 capital stock. Korea: Timmer and Ark (2000) and Korea Statistical Yearbook (various issues). All pre-1953 investment data have been discounted by $40 \%$ to account for war damage. Singapore: Yearbook of Statistics Singapore (various issues). Taiwan: Timmer and Ark (2000) and Taiwan Statistical Data Book (various issues). All data are expressed in constant 1995 dollars valued at PPP.

Patents. Patent data are obtained from the World Intellectual Property Organization (2007).

Research and development (R\&D). Two R\&D measures are considered: real R\&D expenditures $(R)$ and number of R\&D workers $(N)$. The data are obtained from the following sources: China: China Statistical Yearbook (various issues), "Comprehensive Statistical Data and Materials on 50 Years of New China", Beijing: China Statistics Press, "Statistics on Science and Technology of China: 19491989", Peking: Zhongguo Tong Ji Chu Ban She and the various issues of "S\&T Statistics Data Book" published by the Ministry of Science and Technology. Continuous R\&D workers data are not available. Data for the missing years (1952-1959 and 1961-1977) have been filled by the predicted values from regressing $N$ on a constant and the stock of natural sciences graduates, where $N$ was obtained by interpolation. A time trend was initially included but found to be insignificant and therefore dropped from the estimation. India: various issues of "R\&D Statistics" published by the Department of Science and Technology and "Macro-Aggregates" published by the Planning Commission, Government of India. These data are complemented with various issues of the UNESCO Statistical Yearbook published by the United Nations Educational, Scientific, and Cultural Organization (UNESCO). Data on R\&D expenditures are available at five year intervals between 1950 and 1970, and continuously thereafter. Missing data are interpolated using the geometric growth rate. Japan: Japan Statistical Yearbook (various issues). Korea: Korea Statistical Yearbook (various issues) and UNESCO Statistical Yearbook (various issues). Data before 1967 are predicted using the first principal component of the 
data for China, India, Japan and Taiwan. Singapore: Yearbook of Statistics Singapore (various issues). UNESCO Statistical Yearbook (various issues). Data before 1970 are predicted using the first principal component of the data for China, India, Japan and Taiwan. Taiwan: Taiwan Statistical Data Book (various issues) and Statistical Yearbook of the Republic of China (various issues). Data before 1970 are estimated using the first principal component of the number of patents applications (obtained from various issues of "Annual Report" and "Yearbook of Intellectual Property" published by the Taiwan Intellectual Property Office (TIPO)), enrolment numbers in science and engineering courses and R\&D data for China and India. OECD: Data for 1965-2004 are obtained from OECD Main Science and Technology Indicators, OECD Archive (OECDDSTI/EAS), National Science Foundation and Statistics Netherlands. The data are extrapolated to 2006. Earlier year data are obtained from various sources documented in Madsen (2008b).

Nominal R\&D expenditure is deflated using an unweighted average of the economy-wide value-added price deflator and hourly earnings, following Coe and Helpman (1995), to express in real terms. The price deflator is obtained from the same domestic sources as $Y$ and $L$ described above. Except for Japan where the data are available from Japan Statistical Yearbook (various issues), hourly earnings data for all other countries are compiled from the "Yearbook of Labour Statistics", Geneva: International Labour Office and other domestic sources described above. For China, data before 1979 are estimated by assuming that the growth rate of wages equals the sum of labor productivity growth and the inflation rate. Real $R \& D$ capital stock is calculated using the perpetual inventory method. The initial $R \& D$ capital stock is obtained using the same procedure as the physical capital stock $(K)$ with a depreciation rate of $5 \%$.

Human capital. Human capital is measured by the average years of schooling. The estimates of Barro and Lee (2001) are used for India, Korea, Singapore and Taiwan. The data, which are available only for every five years to 2000, are interpolated to get annual series and extrapolated to 2006. Data for China up to 1999 are obtained from Wang and Yao (2003). Following their methodology, the series is extended to 2006 using data from China Statistical Yearbook (various issues). Data for Japan are obtained from Madsen (2009).

Trade openness and bilateral trade weights. Trade openness is measured by the sum of exports and imports over GDP. For the Asian countries, the same sources that are used to obtain $Y$ and $L$ are used here. Except for Taiwan where the data are collected from Taiwan Statistical Data Book (various issues), bilateral trade weights for all countries are constructed using data from the IMF Direction of International Trade Statistics. Data for OECD countries are obtained from Madsen (2007). 


\section{References}

Abdih, Y., and F. Joutz, "Relating the Knowledge Production Function to Total Factor Productivity: An Endogenous Growth Puzzle," IMF Staff Papers 53:2 (2006), 242-271.

Acemoglu, D., P. Aghion, and F. Zilibotti, "Distance to Frontier, Selection, and Economic Growth," Journal of the European Economic Association 4:1 (2006), 37-74.

Aghion, P., and P. Howitt, "A Model of Growth through Creative Destruction," Econometrica 60:2 (1992), 323-351. , Endogenous Growth Theory (Cambridge: MIT Press, 1998). $\overline{79-93 .}$

, "Capital, Innovation, and Growth Accounting," Oxford Review of Economic Policy 23:1 (2007), , The Economic of Growth (Cambridge, Massachusetts: The MIT Press, 2009).

Aghion, P., P. Howitt, and D. Mayer-Foulkes, "The Effect of Financial Development on Convergence: Theory and Evidence," Quarterly Journal of Economics 120:1 (2005), 173-222.

Barro, R. J., and J. W. Lee, "International Data on Educational Attainment: Updates and Implications," Oxford Economic Papers 53:3 (2001), 541-563.

Boehm, K., and A. Silberston, The British Patent System: Administration (Cambridge: Cambridge University Press, 1967).

Breitung, J., "The Local Power of Some Unit Root Tests for Panel Data," (pp. 161-178), in B. Baltagi (Eds.), Advances in Econometrics: Nonstationary Panels, Panel Cointegration, and Dynamic Panels (Amsterdam: JAI Press, 2000).

Choi, I., "Unit Root Tests for Panel Data," Journal of International Money and Finance 20:2 (2001), 249-272.

Coe, D. T., and E. Helpman, "International R\&D spillovers," European Economic Review 39:5 (1995), 859-897.

Coe, D. T., E. Helpman, and A. W. Hoffmaister, "North-South R\&D Spillovers," Economic Journal 107:440 (1997), 134-149.

Dinopoulos, E., and P. Thompson, "Schumpeterian Growth without Scale Effects," Journal of Economic Growth 3:4 (1998), 313-335.

Dowrick, S., and N. Gemmell, "Industrialisation, Catching Up and Economic Growth: A Comparative Study across the World's Capitalist Economies," Economic Journal 101:405 (1991), 263-275.

Easterly, W., "Explaining miracles : growth regressions meet the Gang of Four," The World Bank Policy Research Working Paper No. 1250 (1994). 
Edwards, S., "Openness, Productivity and Growth: What Do We Really Know?," Economic Journal 108:447 (1998), 383-398.

Greasley, D., "The Stationarity of British Economic and Productivity Growth 1856-1913," Journal of Applied Econometrics 7:2 (1992), 203-209.

Griffith, R., S. Redding, and J. V. Reenen, "R\&D and Absorptive Capacity: Theory and Empirical Evidence," Scandinavian Journal of Economics 105:1 (2003), 99-118.

Griliches, Z., "Issues in Assessing the Contribution of Research and Development to Productivity Growth," Bell Journal of Economics 10:1 (1979), 92-116.

Grossman, G. M., and E. Helpman, "Quality Ladders in the Theory of Growth," Review of Economic Studies 58:1 (1991), 43-61.

Ha, J., and P. Howitt, "Accounting for Trends in Productivity and R\&D: A Schumpeterian Critique of Semi-Endogenous Growth Theory," Journal of Money, Credit and Banking 39:4 (2007), 733-774.

Ha, J., Y. J. Kim, and J.-W. Lee, "The Optimal Structure of Technology Adoption and Creation: Basic Research vs. Development in the Presence of Distance to Frontier," ADB Economics Working Paper Series No. 163 (2009).

Hall, B. H., A. Jaffe, and M. Trajtenberg, "Market Value and Patent Citations," RAND Journal of Economics 36:1 (2005), 16-38.

Howitt, P., "Steady Endogenous Growth with Population and R\&D Inputs Growing," Journal of Political Economy 107:4 (1999), 715-730.

, "Endogenous Growth and Cross-Country Income Differences," American Economic Review 90:4 (2000), 829-846.

Im, K. S., M. H. Pesaran, and Y. Shin, "Testing for Unit Roots in Heterogeneous Panels," Journal of Econometrics 115:1 (2003), 53-74.

Jones, C., "R\&D Based Models of Economic Growth," Journal of Political Economy 103:4 (1995a), 759-784.

, "Time Series Tests of Endogenous Growth Models," Quarterly Journal of Economics 110:2 (1995b), 495-525.

Kao, C., "Spurious Regression and Residual-Based Tests for Cointegration in Panel Data," Journal of Econometrics 90:1 (1999), 1-44.

Kim, J.-I., and L. J. Lau, "The Sources of Economic Growth of the East Asian Newly Industrialized Countries," Journal of the Japanese and International Economies 8:3 (1994), 235-271.

Kneller, R., and P. A. Stevens, "Frontier Technology and Absorptive Capacity: Evidence from OECD Manufacturing Industries," Oxford Bulletin of Economics and Statistics 68:1 (2006), 1-21. 
Kortum, S., "Research, Patenting, and Technological Change," Econometrica 65:6 (1997), 1389-1419.

Krugman, P., "The Myth of Asia's Miracle," Foreign Affairs 73:6 (1994), 62-78.

Lee, J., and M. C. Strazicich, "Minimum Lagrange Multiplier Unit Root Test with Two Structural Breaks," Review of Economics and Statistics 85:4 (2003), 1082-1089.

Levin, A., C. F. Lin, and C. Chu, "Unit Root Tests in Panel Data: Asymptotic and Finite-Sample Properties," Journal of Econometrics 108:1 (2002), 1-24.

Lichtenberg, F. R., and B. van Pottelsberghe de la Potterie, "International R\&D Spillovers: A Comment," European Economic Review 42:8 (1998), 1483-1491.

Maddala, G. S., and S. Wu, "A Comparative Study of Unit Root Tests with Panel Data and A New Simple Test," Oxford Bulletin of Economics and Statistics 61:0 (1999), 631-652.

Madsen, J. B., "Technology Spillover through Trade and TFP Convergence: 135 Years of Evidence for the OECD Countries," Journal of International Economics 72:2 (2007), 464-480.

, "Economic Growth, TFP Convergence and the World Export of Ideas: A Century of Evidence," Scandinavian Journal of Economics 110:1 (2008a), 145-167.

"Semi-Endogenous versus Schumpeterian Growth Models: Testing the Knowledge Production Function using International Data," Journal of Economic Growth 13:1 (2008b), 1-26. (2009).

"Growth, Human Capital, and the World Technology Frontier," Mimeo, Monash University

Madsen, J. B., S. Saxena, and J. B. Ang, "The Indian Growth Miracle and Endogenous Growth," Journal of Development Economics, forthcoming (doi:10.1016/j.jdeveco.2009.06.002):(2009).

Ng, S., and P. Perron, "Lag Length Selection and the Construction of Unit Root Tests with Good Size and Power," Econometrica 69:6 (2001), 1519-1554.

Pedroni, P., "Panel Cointegration: Asymptotic and Finite Sample Properties of Pooled Time Series Tests with an Application to the PPP Hypothesis," Econometric Theory 20:3 (2004), 597-625.

Peretto, P., "Technological Change and Population Growth," Journal of Economic Growth 3:4 (1998), 283-311.

Peretto, P., and S. Smulders, "Technological Distance, Growth and Scale Effects," Economic Journal 112:481 (2002), 603-624.

Peretto, P. F., "Industrial Development, Technological Change, and Long-run Growth," Journal of Development Economics 59:2 (1999), 389-417.

Radelet, S., J. Sachs, and J.-W. Lee, "The Determinants and Prospects of Economic Growth in Asia," International Economic Journal 15:3 (2001), 1-29. 
Rivera-Batiz, L. A., and P. M. Romer, "Economic Integration and Endogenous Growth," Quarterly Journal of Economics 106:2 (1991), 531-555.

Rodrik, D., "Getting Interventions Right: How South Korea and Taiwan Grew Rich," Economic Policy 10:20 (1995), 55-107.

, "Coordination Failures and Government Policy: A Model with Applications to East Asian and Eastern Europe," Journal of International Economics 40:1-2 (1996), 1-22.

, "The 'Paradoxes' of the Successful State," European Economic Review 42:3-5 (1997), 411-442.

Romer, P. M., "Endogenous Technological Change," Journal of Political Economy 98:5 (1990), S71102.

Savvides, A., and M. Zachariadis, "International Technology Diffusion and the Growth of TFP in the Manufacturing Sector of Developing Economies," Review of Development Economics 9:4 (2005), 482501.

Segerstrom, P. S., "Endogenous Growth without Scale Effects," American Economic Review 88:5 (1998), 1290-1310.

Segerstrom, P. S., T. C. A. Anant, and E. Dinopoulos, "A Schumpeterian Model of the Product Life Cycle," American Economic Review 80:5 (1990), 1077-1091.

Timmer, M., and B. v. Ark, "Capital Formation and Productivity Growth in South Korea and Taiwan: Beating Diminishing Returns through Realising the Catch-Up Potential," Paper Presented at the 26th General Conference of The International Association for Research in Income and Wealth, Cracow, Poland (2000).

Vamvakidis, A., "How Robust is the Growth-Openness Connection? Historical Evidence," Journal of Economic Growth 7:1 (2002), 57-80.

Wang, Y., and Y. Yao, "Sources of China's Economic Growth 1952-1999: Incorporating Human Capital Accumulation," China Economic Review 14:1 (2003), 32-52.

Young, A., "Accumulation, Exports and Growth in the High Performing Asian Economies," CarnegieRochester Conference Series on Public Policy 40:1 (1994), 237-250.

, "The Tyranny of Numbers: Confronting the Statistical Realities of the East Asian Growth Experience," Quarterly Journal of Economics 110:3 (1995), 641-680.

, "Growth without Scale Effects," Journal of Political Economy 106:1 (1998), 41-63.

Zachariadis, M., "R\&D, Innovation, and Technological Progress: A Test of the Schumpeterian Framework without Scale Effects," Canadian Journal of Economics 36:3 (2003), 566-586.

, "R\&D-Induced Growth in the OECD?," Review of Development Economics 8:3 (2004), 423-439. 
